E

51

.1393

no. 16 NMAIREF

NDIAN NOTES

D MONOGRAPHS

EDITED BY F. W. HODGE

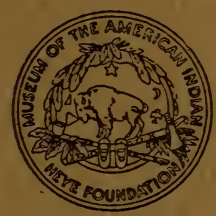

A SERIES OF PUBLICATIONS RELATING TO THE AMERICAN ABORIGINES

\title{
STRING RECORDS OF THE NORTHWEST
}

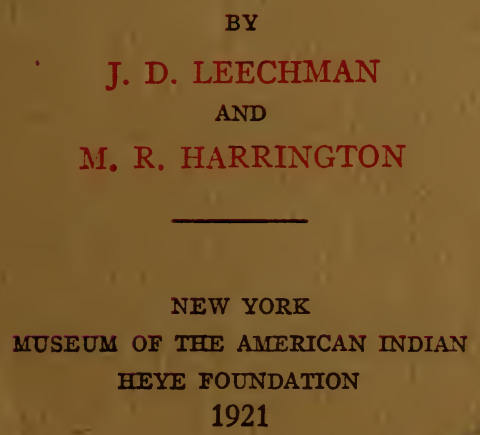


THIS series of IndIAN Notes AND MonoGRAPHS is devoted primarily to the publication of the result of studies by members of the staff of the Museum of the American Indian, Heye Foundation, and is uniform with HISPANIC Notes AND MoNOGRAPHS, published by the Hispanic Society of America, with which organization this Museum is in cordial coöperation.

Only the first ten volumes of INDIAN NOTES AND MONOGRAPHS are numbered. The unnumbered parts may readily be determined by consulting the List of Publications issued as one of the series. 



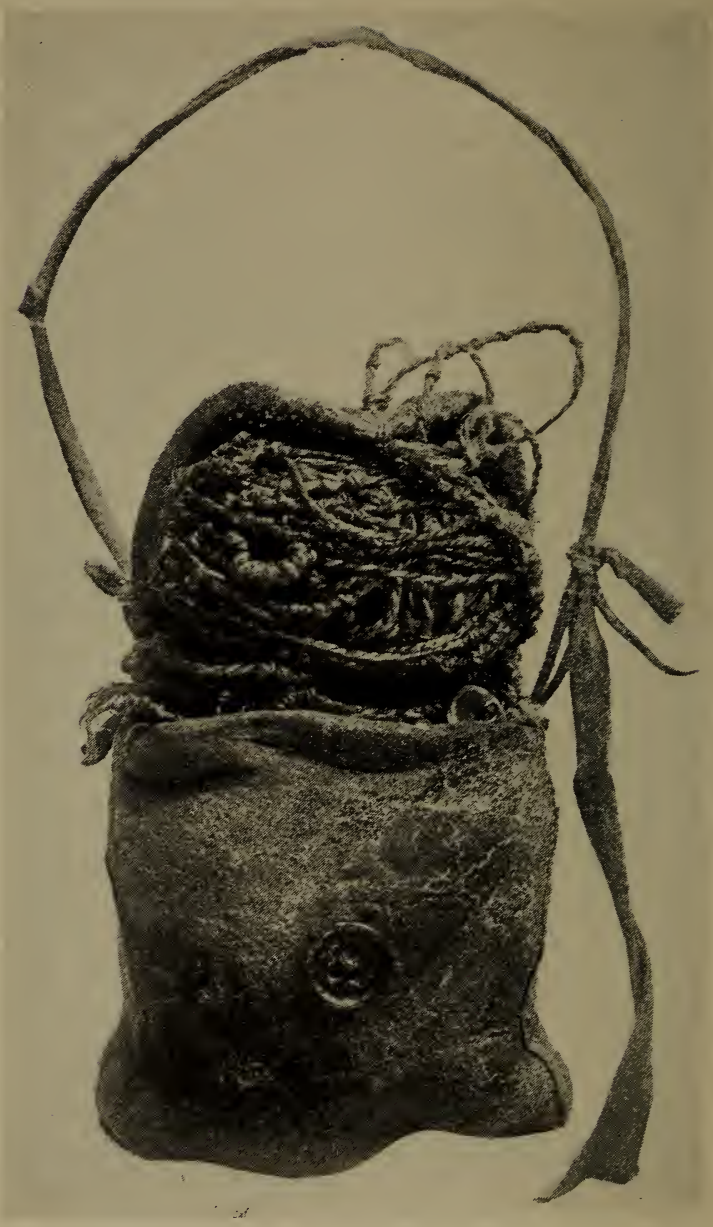

CASE CONTAINING STRING RECORD 1, NICOLA VALLEY, B. C. (Width, 3 in.) 


\title{
INDIAN NOTES AND MONOGRAPHS
}

EdITED By F. W. HODGE

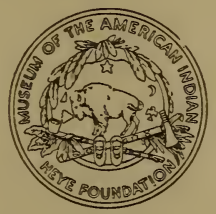

A SERIES OF PUBLICATIONS RELATING TO THE AMERICAN ABORIGINES

\section{STRING RECORDS OF THE NORTHWEST}

\author{
BY \\ J. D. LEECHMAN \\ AND \\ M. R. HARRINGTON
}

NEW YORK

MUSEUM OF THE AMERICAN INDIAN

HEYE FOUNDATION

1921 



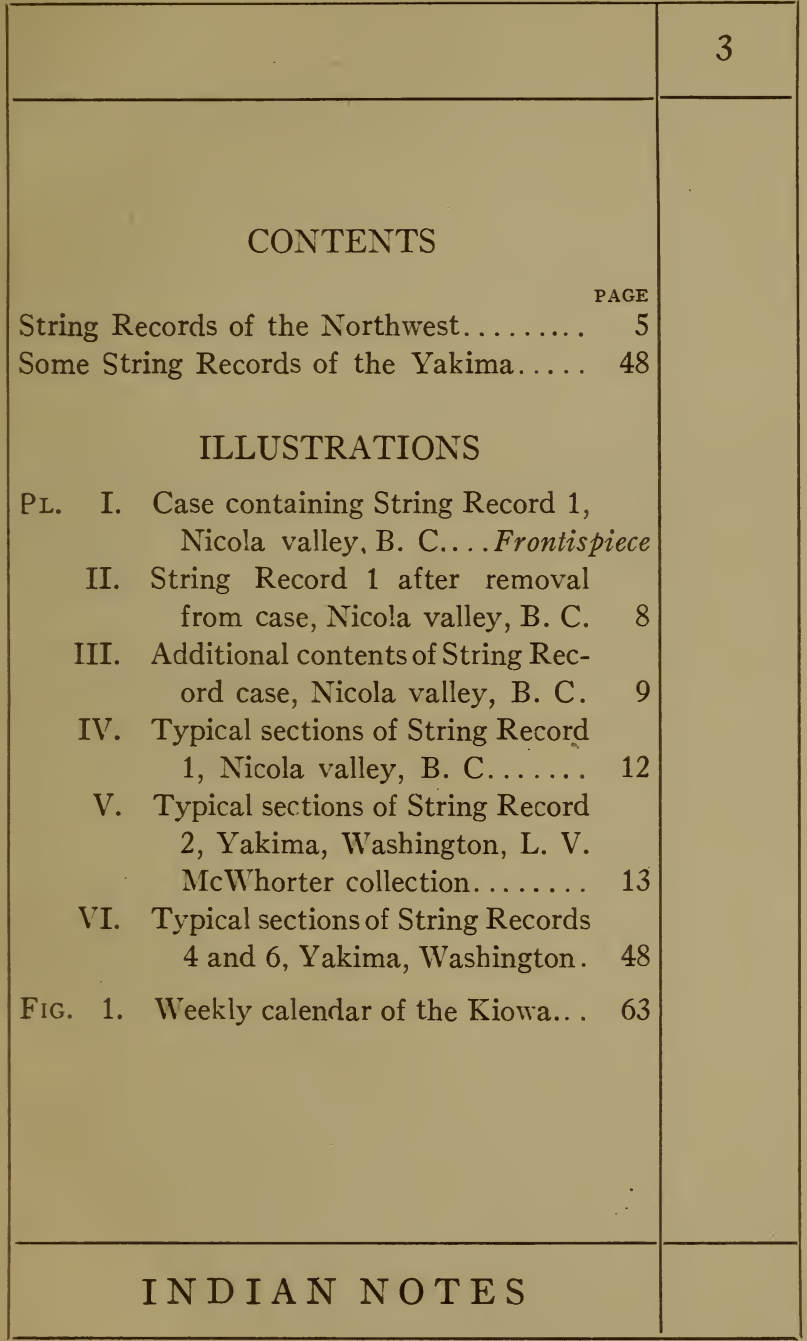





\begin{tabular}{|}
\hline STRING RECORDS OF THE \\
NORTHWEST \\
By J. D. LEECHNAN \\
records by means of knots tied \\
in string seems to be restricted, \\
in North America, to the interior \\
Salish and neighboring tribes of the North- \\
west. One specimen of such a record has \\
been seen by the author from Nicola valley \\
in southern British Columbia, and two from \\
the neighborhood of Yakima, Washington. \\
No mention of such records is made in any \\
of the literature dealing with this district \\
to which the author has had access, and it \\
is believed that their existence is not \\
generally recognized. \\
These records differ from the quipu of \\
$\begin{array}{l}\text { South America in that their basic principle } \\
\text { is chronological and not numerical. While } \\
\text { the quipu is based on the decimal system, }\end{array}$ \\
I N D I A N N O T E S
\end{tabular}




\begin{tabular}{|c|c|}
\hline 6 & STR I N R E C OR D S \\
\hline & $\begin{array}{l}\text { and consists of a main cord with dependent } \\
\text { strings, }{ }^{1} \text { the records here described are } \\
\text { formed of one string only, with groups of } \\
\text { simple knots tied in it, each knot represent- } \\
\text { ing a day and each group apparently a week, } \\
\text { though many of the groups consist of more } \\
\text { or less than seven knots, and so an irregular- } \\
\text { ity is introduced which is not easy of } \\
\text { explanation. } \\
\text { These knots are frequently distinguished } \\
\text { by various markers which differ in color, } \\
\text { size, material, and, apparently, in impor- } \\
\text { tance, and are not of necessity placed at } \\
\text { regular intervals. In one record (Spec. 2), } \\
\text { the property of Mr L. V. McWhorter, of } \\
\text { Yakima, which he was good enough to } \\
\text { lend for examination and illustration, the } \\
\text { markers are at practically regular intervals, } \\
\text { while the knots are usually in groups of } \\
\text { seven. He states that the markers, in this } \\
\text { case beads, indicate moons, and as they } \\
\text { occur every twenty-eight knots, this seems } \\
\text { to be a correct explanation. In the speci- } \\
\text { men from Nicola valley (Spec. 1), however, } \\
\text { this theory falls to the ground, for the spac- }\end{array}$ \\
\hline & INDIAN NOTES \\
\hline
\end{tabular}




\section{N O R T H W E T E R N}

ing of both markers and groups is very irregular.

It appears from the statements of informants that such a biographical record is often commenced, by the mother, at the birth of the child, and that it serves not only to record its age but any unusual happenings in its life. A letter from Mr James Teit, of Spence's Bridge, British Columbia, well known for his ethnological studies of the Salish Indians, gives the following information:

There seems to be little doubt of its being a record such as numbers of the old Indians used to keep. I have seen several of them in use. These records are individual and therefore cannot be interpreted correctly or even approximately in most cases by any other than the owner. Days, weeks, months, and years are marked by different knots or marks, different individuals using somewhat different systems. Other markers generally representing special happenings or dates consist of attachments or wrappings of rag, bark, string, hair, sinew, etc. Colors are occasionally used in a systematic way. Other records are made on hide and wood, generally by notching, etc., and sometimes painting, etc., but string records are much more common. You speak of the material koiskana-kó-is or kwoes is the name of the

\section{A N D MONOGRAPHS}




\begin{tabular}{|c|c|}
\hline 8 & \multicolumn{1}{|c|}{ S T R I N G R E C O R D S } \\
\hline $\begin{array}{l}\text { material, the name koiskana being that of a } \\
\text { place seemingly originating from the name of } \\
\text { the material. Some necklaces used in this dis- } \\
\text { trict consisted of bark or buckskin with knots } \\
\text { and wrappings of hair, etc., between, but it } \\
\text { seems your specimen is evidently a record. } \\
\text { Inquiries among the Indians of Cape } \\
\text { Flattery and Puget sound have resulted in } \\
\text { answers which lead to the conclusion that } \\
\text { this system of records was unknown to } \\
\text { them. } \\
\text { Another record (Spec. 3), at present in } \\
\text { the Museum at the University of Washing- } \\
\text { ton, was lent to the author for the purpose } \\
\text { of securing a photograph, but permission } \\
\text { to unwind the ball was not obtained. It is } \\
\text { tied into knots as are the others, with } \\
\text { markers of beads and shells, but it was not } \\
\text { possible to confirm the impression that these } \\
\text { markers are arranged in groups indicating } \\
\text { lunar phases, as in the Yakima specimen. } \\
\text { The specimen from Nicola valley (Spec. } \\
\text { 1) is now in the Museum of the American } \\
\text { Indian, Heye Foundation, and was found } \\
\text { by the writer in 1911, hanging on a corner- } \\
\text { post of a fence surrounding an Indian grave } \\
\text { in a cemetery near the Indian village of }\end{array}$ \\
\hline I N D I A N N O T E S \\
\hline
\end{tabular}




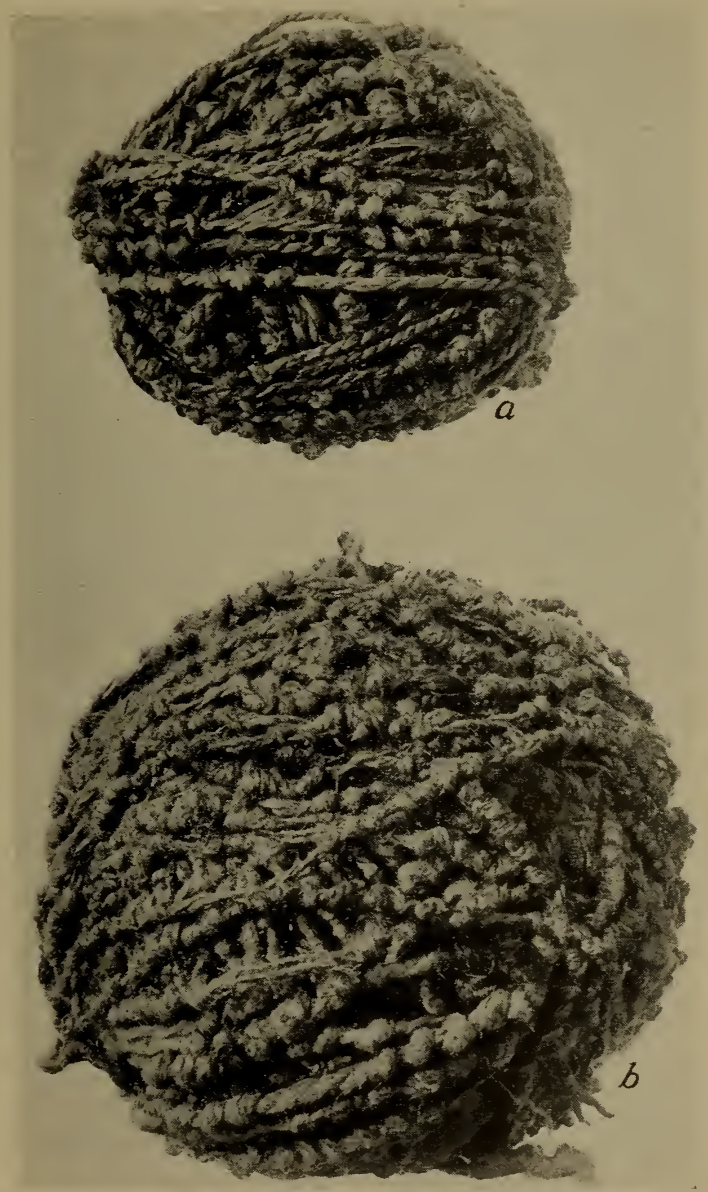

STRING RECORD 1 AFTER REMOVAL FROM CASE NICOLA VALLEY, B. C.

(Diameter of $b, 2.8 \mathrm{in}$.) 


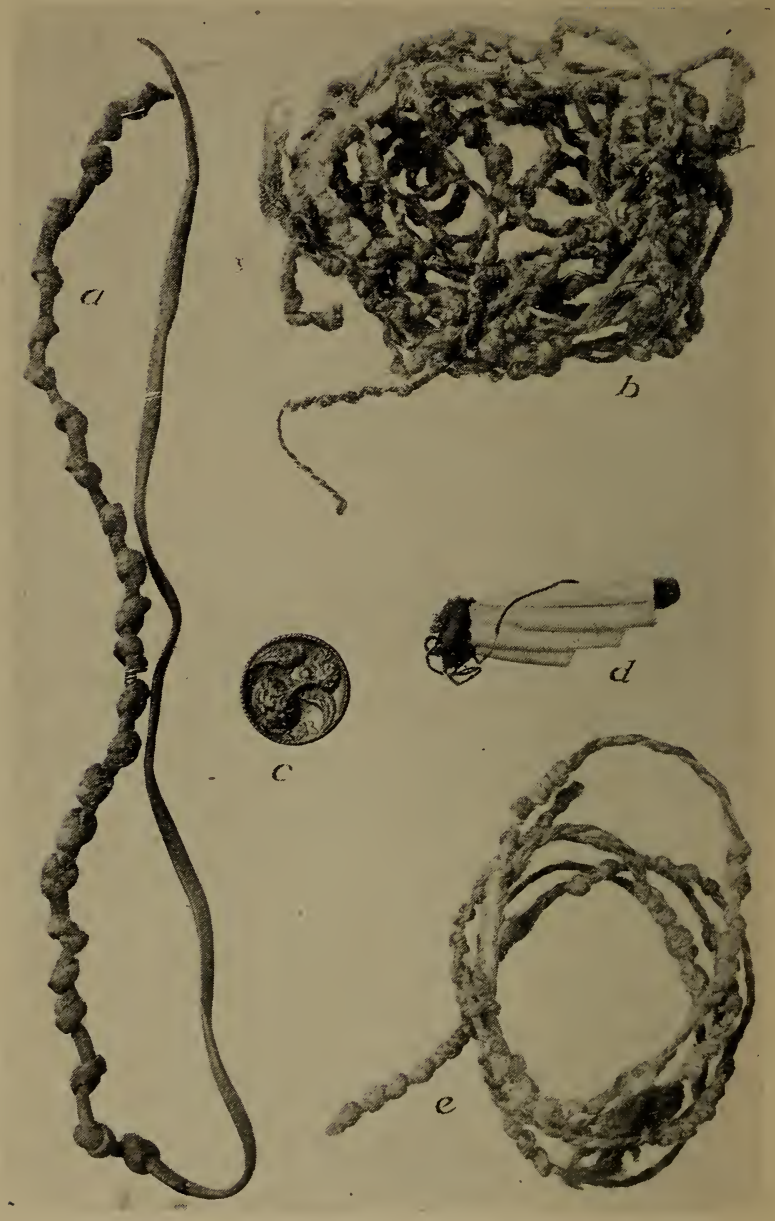

ADDITIONAL CONTENTS OF STRING RECORD CASE, NICOLA VALLEY, B. C.

(Length of $d .1 .5 \mathrm{in.}$ ) 


\section{N I C O L A V A L L E Y}

Tsulus, in Nicola valley, about four miles north of Merritt, British Columbia.

It is a carefully made bag of deerskin (pl. I), provided with a single loop of the same material attached at the back, and secured in front by a single button, apparently an ordinary metal trousers button. In it were found the following objects:

(1) A large ball of string (pl. II, $a$ ), composed principally of the bark of the dogbane (A pocynum canabinum) known to the Indians as kois. The string is about 180 feet in length and is tied into more than 6,600 simple knots.

(2) A smaller ball of cord of the same material (pl. II, $b$ ), about 33 feet long and tied into about 1,400 knots.

(3) A third cord (pl. III, $b$ ), not rolled into a ball, seven feet long and tied into 308 knots.

(4) A brass button (pl. III, c), 0.7 in. in diameter, with an ornate design representing a tree and butterflies in bold relief. A wing appears on each side of the trunk of the tree. The button has a plain metal back with a metal shank for attaching it to clothing, and is spotted with verdigris.

\section{A N D MONOGRAPHS}




\begin{tabular}{|c|c|}
\hline 10 & S T R I G R E C R D S \\
\hline & $\begin{array}{l}\text { (5) A leather shoe-lace, } 16 \text { in. in length, } \\
\text { (pl. III, a), with } 24 \text { knots fairly equally } \\
\text { spaced, but occupying only } 7.5 \text { in., the re- } \\
\text { mainder of the strip being without knots. } \\
\text { (6) Four dentalium shells (pl. III, } d \text { ), } \\
\text { threaded on fine strips of sinew. The shells } \\
\text { are of slightly different lengths, as follows: } \\
0.6 \text { in., } 0.98 \text { in., } 1.12 \text { in., } 1.08 \text { in. The four } \\
\text { sinew threads on which they are strung } \\
\text { are attached at their ends to a small bit } \\
\text { of leather so that the shells lie parallel to } \\
\text { one another and in the same plane. } \\
\text { The larger ball was tightly wound. Com- } \\
\text { mencing at the inner end the knots were } \\
\text { tied in groups (pl. Iv, } a, b, c \text { ), following an } \\
\text { initial blank space about two inches long, } \\
\text { as shown in the Table, Specimen } 1 \text {, a, pp. } \\
\text { 16-35. } \\
\text { The smaller ball'has a loose piece of string } \\
\text { (pl. III, } e \text {; Iv, } h, i, j \text { ), wrapped round it, } \\
\text { about } 33 \text { in. in length, knotted as shown in } \\
\text { the Table, Specimen } 1, b, \text { p. } 36 \text {. } \\
\text { After unwinding about } 11.5 \text { ft. of the } \\
\text { ball itself, it was found to be tied about } \\
\text { with a strip of kois, passed three times } \\
\text { round the ball and then tied in a half-bow. }\end{array}$ \\
\hline & I N D I A NOTES \\
\hline
\end{tabular}




\section{Y A K I M A}

A little more than two feet of the inner end of the string is left unrestrained by the band. No knot was found at the free end of this string, in which respect it differs from all the others. It is knotted as shown in the Table, Specimen 1, c, pp. 37-38.

The shortest string (pl. III, $b$; vI, $d, e, f, g$ ), which is not included in either of the two balls, is $6 \mathrm{ft}$. $11.25 \mathrm{in}$. in length, and is notable for more variations in color than any of the others. It is knotted as shown in the Table, Specimen 1, $d$, pp. 39-41.

It will be noted that the rule is six knots in a group, though there are many exceptions. The general character of the knots and markers on these strings may be seen in pl. IV. In the specimen from Yakima; owned by Mr McWhorter (Spec. 2), as shown in the Table, pp. 42-47, seven knots in the group is almost invariable, which makes it much easier to fit into our calendar. The space between groups is probably to be considered as marking Sunday in the Nicola and similar valley specimens.

Specimen 2 is thus described by $\mathrm{Mr}$ McWhorter: "I am sending you . . .

\section{A ND MONOGRAPHS}




\begin{tabular}{|l|l|}
\hline 12 & \multicolumn{1}{|c}{ S T R I N G R E C O R D S } \\
\hline $\begin{array}{l}\text { one of the string records, not thinking it } \\
\text { necessary to send both, since they are prac- } \\
\text { tically identical duplicates. Both pertain to } \\
\text { the record age of a boy, first twenty years, } \\
\text { knot for each day. In the years it is the } \\
\text { only specimen of its kind that I have ever } \\
\text { been able to secure." In a later letter he } \\
\text { adds that the specimen, when he received } \\
\text { it, was wound on a piece of card instead of } \\
\text { being spherical. "Usually," says Mr Mc- } \\
\text { Whorter, "these relics are highly prized } \\
\text { by the owners." } \\
\text { On examination, this record was found } \\
\text { to be 40 ft. long and tied into 1,238 knots } \\
\text { which are arranged with few exceptions } \\
\text { in groups of seven, as may be seen in the } \\
\text { typical sections shown in pl. v. There are } \\
\text { 4t markers, all beads, and they are placed } \\
\text { regularly after every 28 knots, with occa- } \\
\text { sional exceptions. The material throughout } \\
\text { the string is, as in the preceding specimen, } \\
\text { dogbane (Apocymum), the Yakima name } \\
\text { for which is taxî's, according to Dr Water- } \\
\text { man. The record is carefully made, but } \\
\text { here and there small shreds of the outer } \\
\text { bark still adhere to the fiber. Its color is }\end{array}$ \\
\hline \begin{tabular}{l} 
I N D I A N N O T E S \\
\hline
\end{tabular} \\
\hline
\end{tabular}




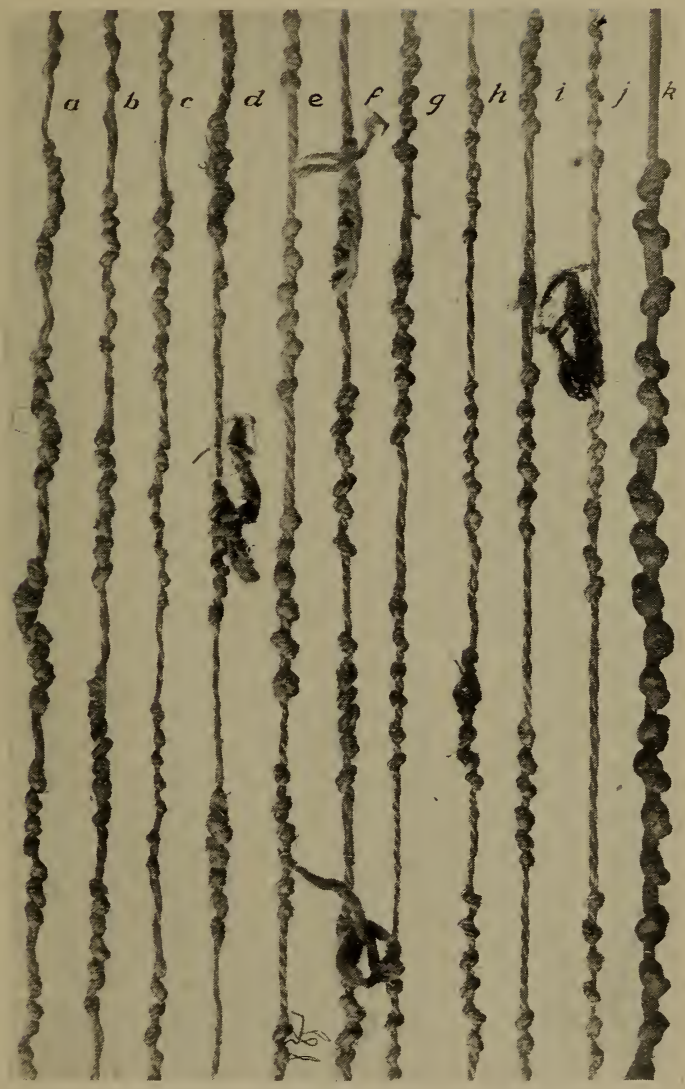

TYPICAL SECTIONS OF STRING RECORD 1, NICOLA VALLEY, B. C.

(Length of sections, 6.5 in.) 


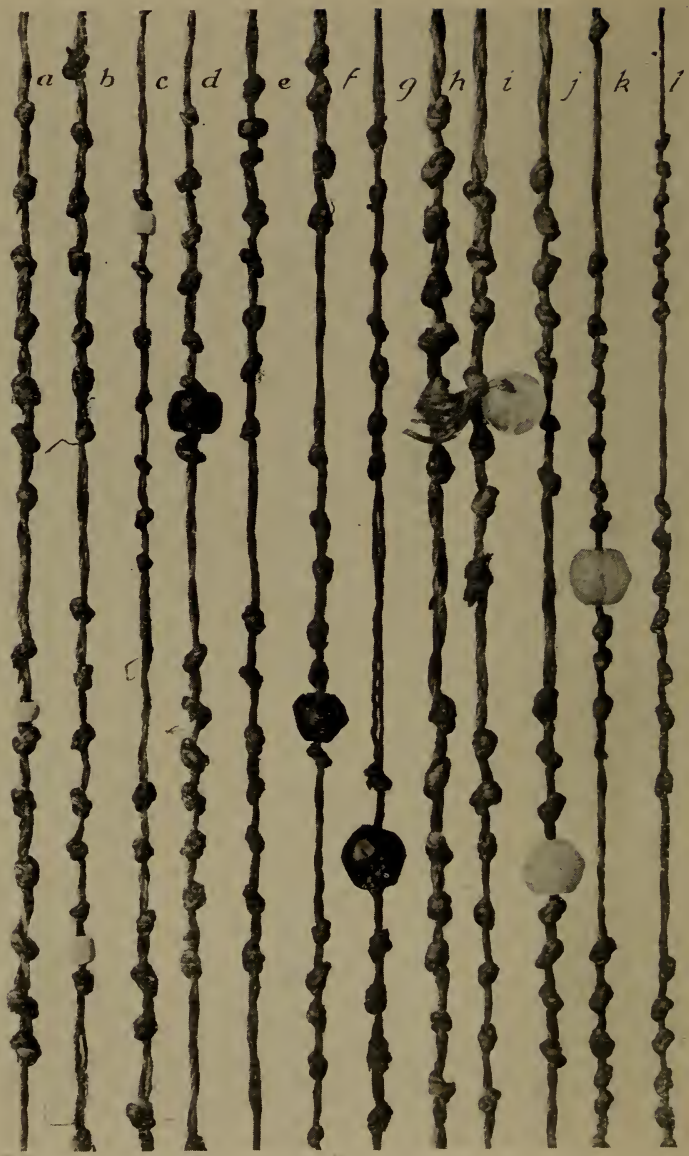

TYPICAL SECTIONS OF STRING RECORD 2, YAKIMA, WASHINGTON. L. V. MCWHORTER COLLECTION 
buff, with the exception of one short length of less than an inch, where it is stained red, apparently without intention.

It is very regular in knotting and marking, as will be noticed in the tabulation, which starts from the inner end. It is worthy of note that the first two or three inches of the string are made with great care and the knots are small, perhaps symbolical of the smallness of the child and of the care it needed.

It is difficult to agree with Mr McWhorter's belief that this record covers a period of twenty years, as only forty-three lunar months are shown. It is probable that he has misunderstood his informant or that the latter was in error himself. The occasional occurrence of six knots in a group where seven would be expected may be laid to errors on the part of the maker, but the solution of the tens and the twelve offers greater difficulties. It is not probable that these Indians were sufficiently expert calendar makers to reckon intercalary days, and the use of the beads shows that the whites had already penetrated the

\section{A N D MONOGRAPHS}




\begin{tabular}{|c|c|}
\hline 14 & STRING RECORDS \\
\hline & $\begin{array}{l}\text { country so that in all probability our } \\
\text { system of time-keeping had been adopted } \\
\text { by them. } \\
\text { The specimen in the Museum at the } \\
\text { University of Washington (Spec. 3) is } \\
\text { similar to the others, except that it is made of } \\
\text { buckskin instead of the native fiber-string } \\
\text { employed in the other examples. It makes } \\
\text { a ball about five inches in diameter, and the } \\
\text { markers seen consist of beads. Whether } \\
\text { other markers are used or not, and whether } \\
\text { they are placed at regular intervals, it is } \\
\text { impossible to determine, as permission to } \\
\text { unwind the ball could not be obtained. The } \\
\text { label states that it is the history of an old } \\
\text { woman of the Yakima, and no other infor- } \\
\text { mation concerning it is available. One of } \\
\text { the markers visible in the illustration con- } \\
\text { sists of a disc of mother-of-pearl; another is } \\
\text { a little brass bell, and a third is a shell } \\
\text { resembling a cowry. } \\
\text { It is unfortunate that it has not been } \\
\text { possible to obtain an explanation of the } \\
\text { markers on any of these records from its } \\
\text { original owner. Those to whom Speci- } \\
\text { mens } 1 \text { and } 3 \text { belonged are dead, and what }\end{array}$ \\
\hline & I N I A N NOTES \\
\hline
\end{tabular}




\section{N O R T H W E S T E R N}

little information we have concerning Specimen 2 is obviously incorrect. It is possible that the owner of this is still living, but no information as to his identity is available. Mr Teit's statement that he has seen these records in use, leads to the hope that an accurate interpretation may still be obtained before their use is abandoned. It would be of great interest to know what events were considered worthy of record, and just how accurate was the remembrance of them, when, as is the case in Specimen 1, there are altogether more than a hundred markers. and no two of them are identical.

\section{NOTE}

1. Leland Locke, The Ancient Quipu, a Peruvian Knot Record, American Anthropologist, N. S., XIV, 325, Apr.-June 1912.

\section{A ND MONOGRAPHS}




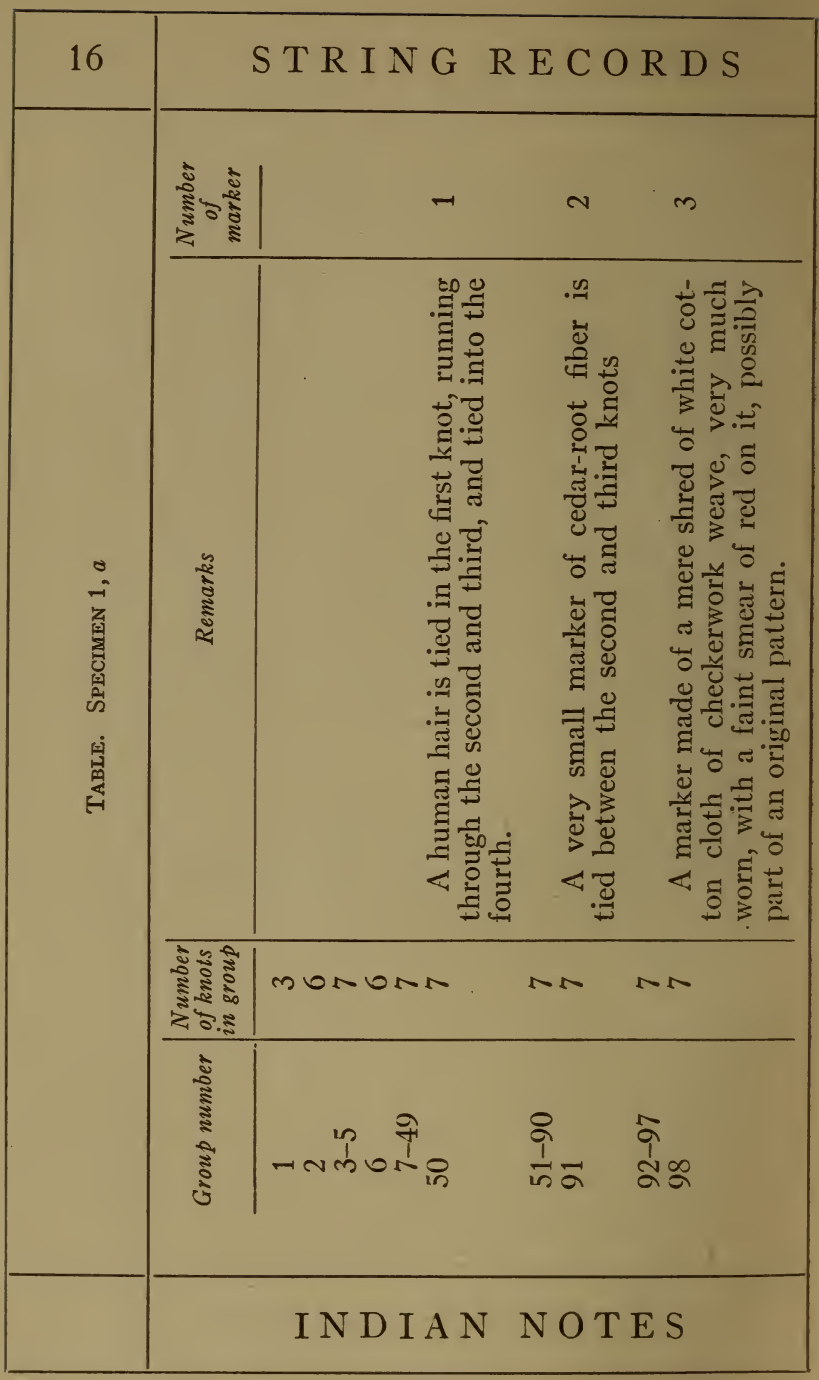




\begin{tabular}{|c|c|c|c|c|c|}
\hline \multicolumn{5}{|c|}{ N I C O L A V A L L E Y } & 17 \\
\hline$H$ & in & 0 & 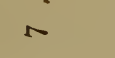 & $\infty$ & \\
\hline 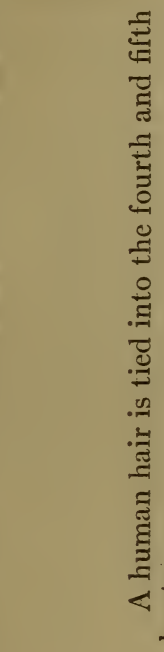 & 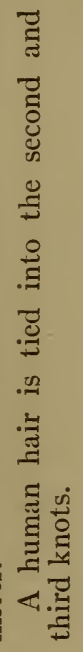 & 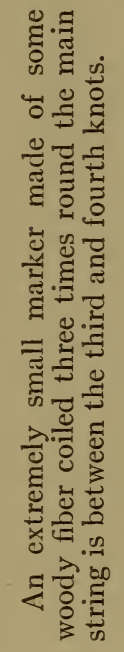 & 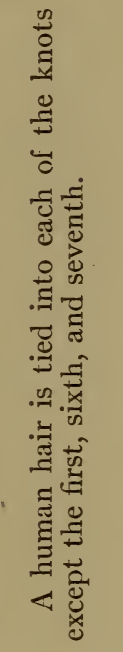 & 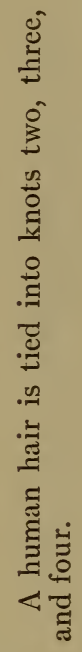 & \\
\hline non & $\wedge$ & $n$ & - & & \\
\hline 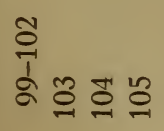 & 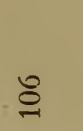 & $\stackrel{\circ}{\stackrel{9}{*}}$ & $\frac{\frac{m}{7}}{\frac{1}{1}}$ & & \\
\hline A N D & M O & NOGR & APHS & & \\
\hline
\end{tabular}




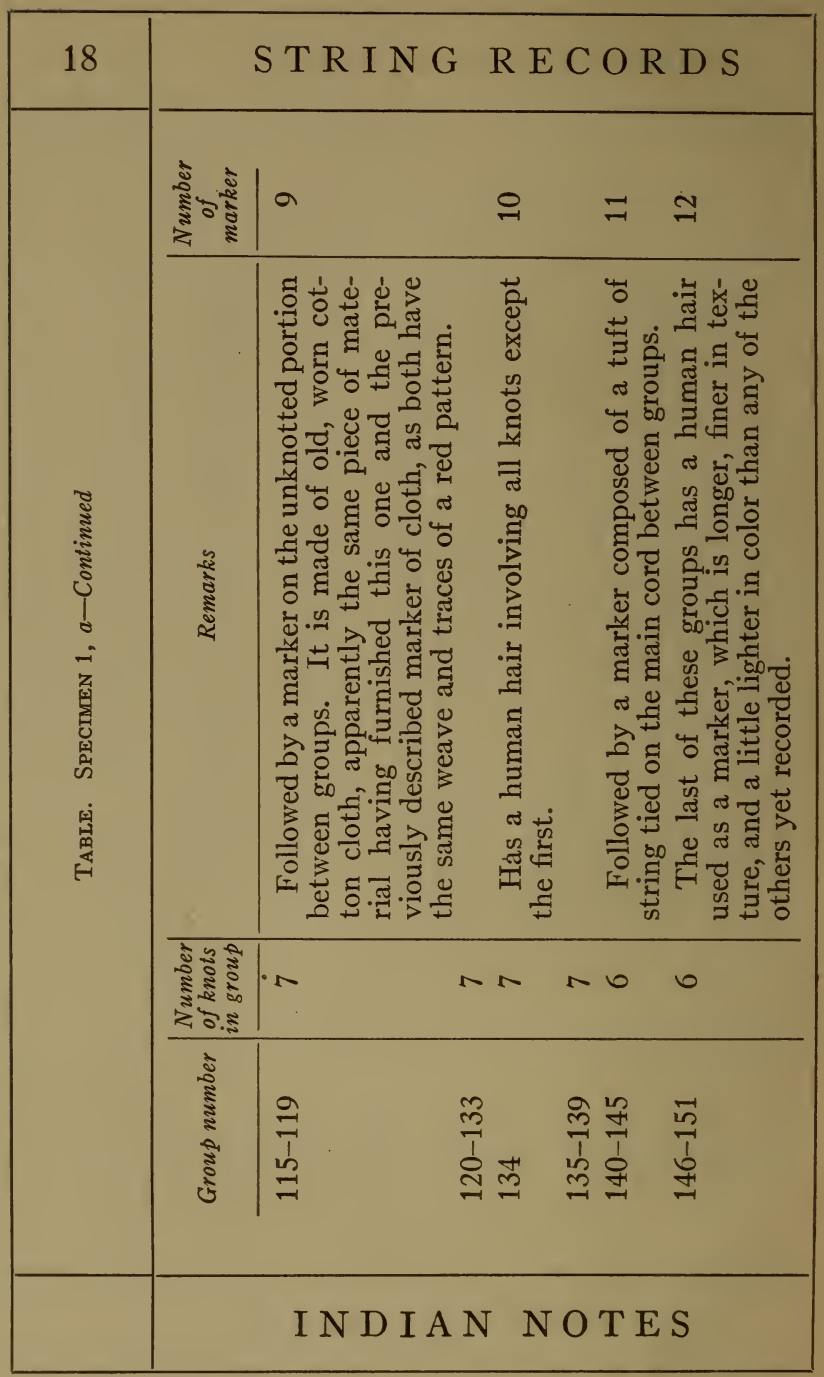




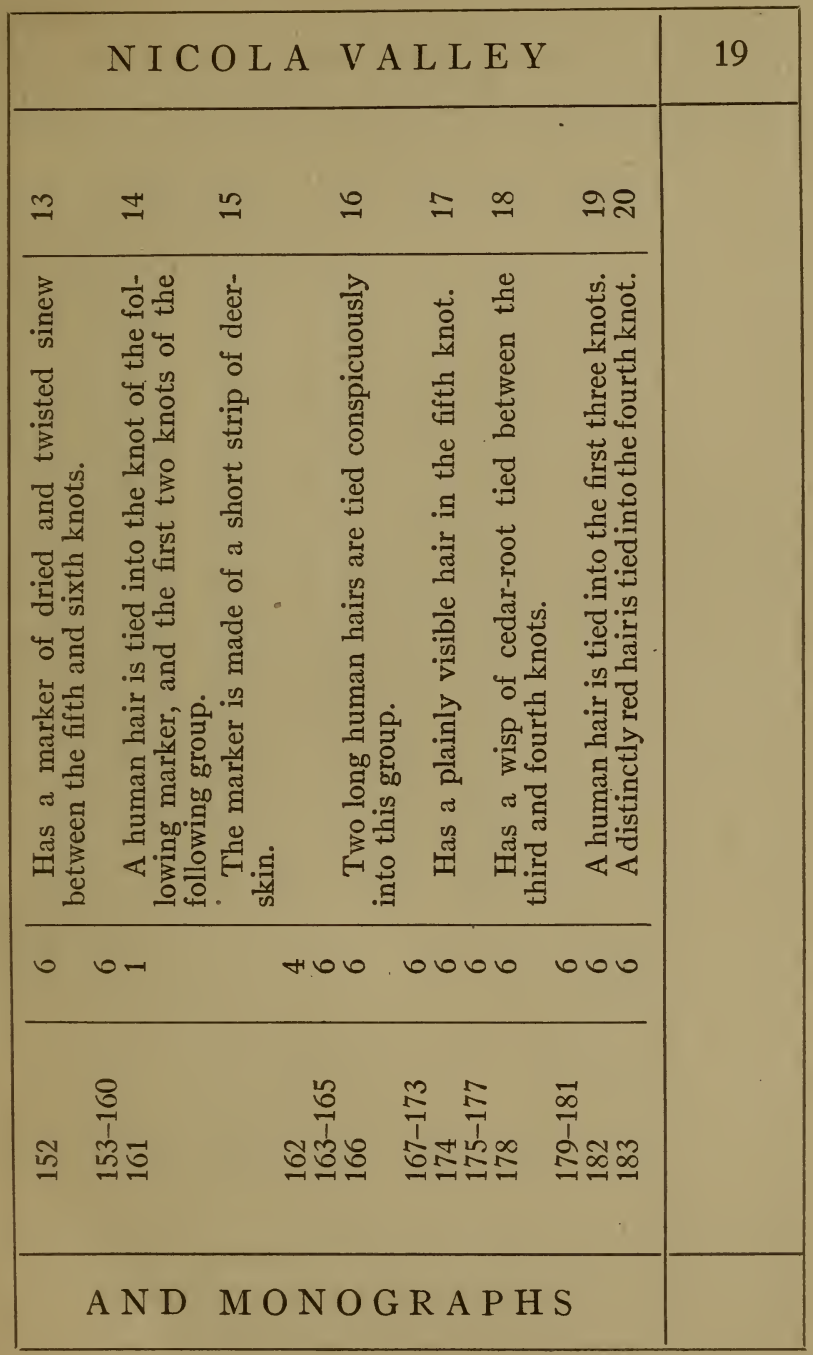




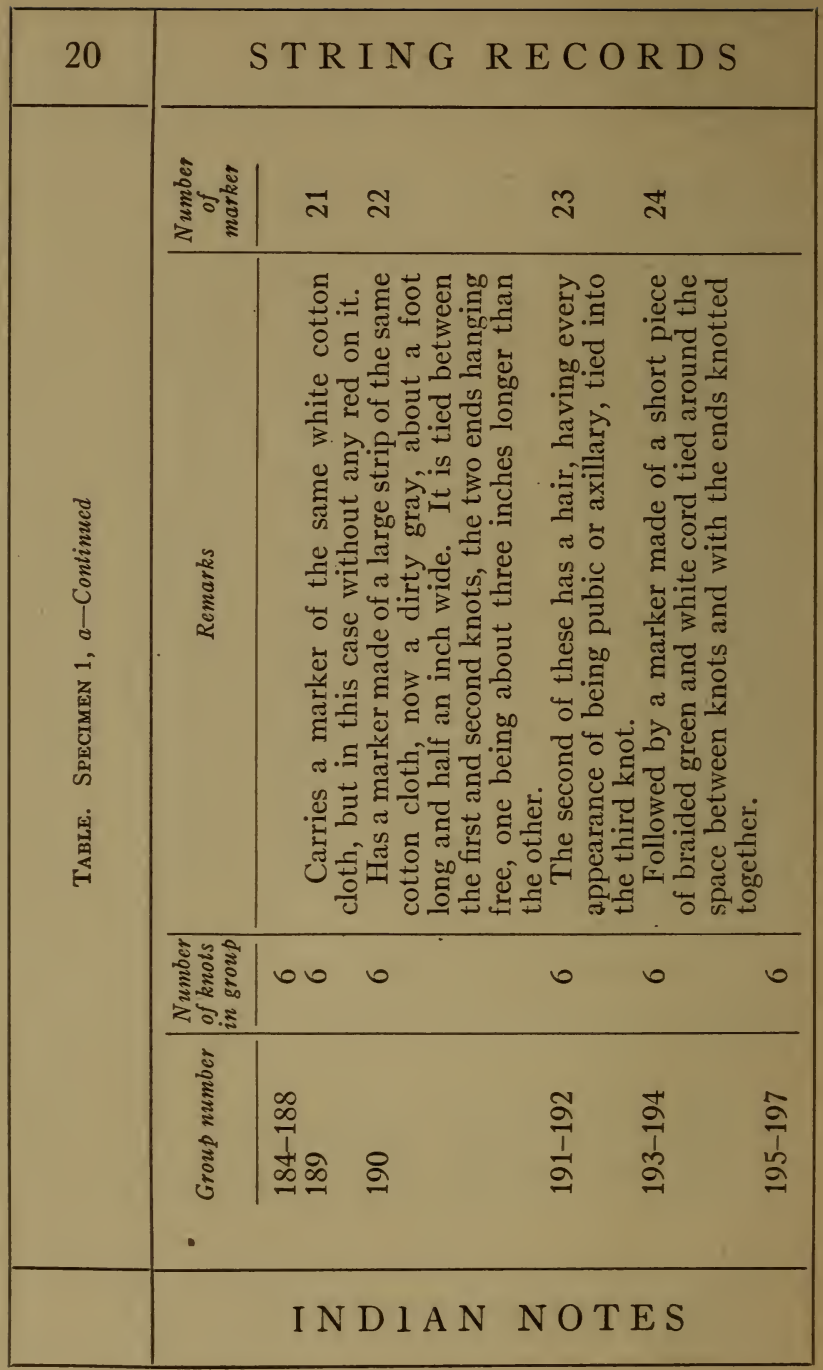




\begin{tabular}{|c|c|c|c|c|c|c|}
\hline \multicolumn{6}{|c|}{ N I C O L A V A L L E Y } & 21 \\
\hline$\stackrel{4}{4}$ & $\stackrel{\sim}{\sim}$ ก & নे & 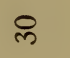 & $\vec{m}$ & & \\
\hline 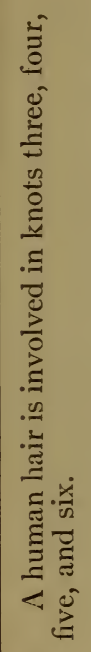 & 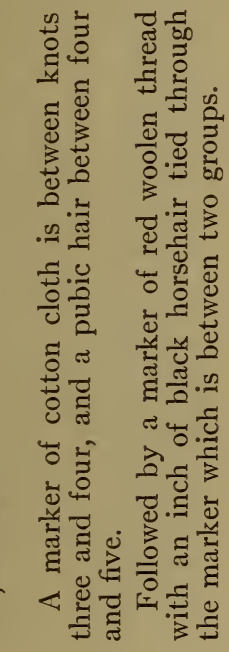 & 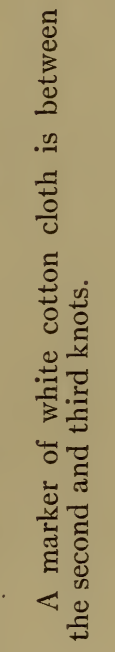 & 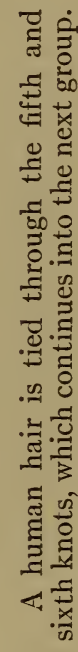 & 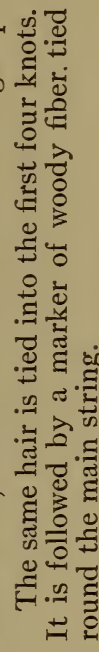 & & \\
\hline 0 & 00 & 00 & 0 & 0 & 0 & \\
\hline & 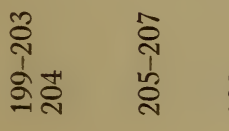 & 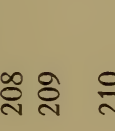 & $\vec{\sim}$ & $\approx$ & $\begin{array}{l}\underset{\vec{N}}{N} \\
\stackrel{\vec{n}}{N}\end{array}$ & \\
\hline & $\mathrm{AND} \mathrm{MON}$ & NO G F & R A P & $\mathrm{H} \mathrm{S}$ & & \\
\hline
\end{tabular}




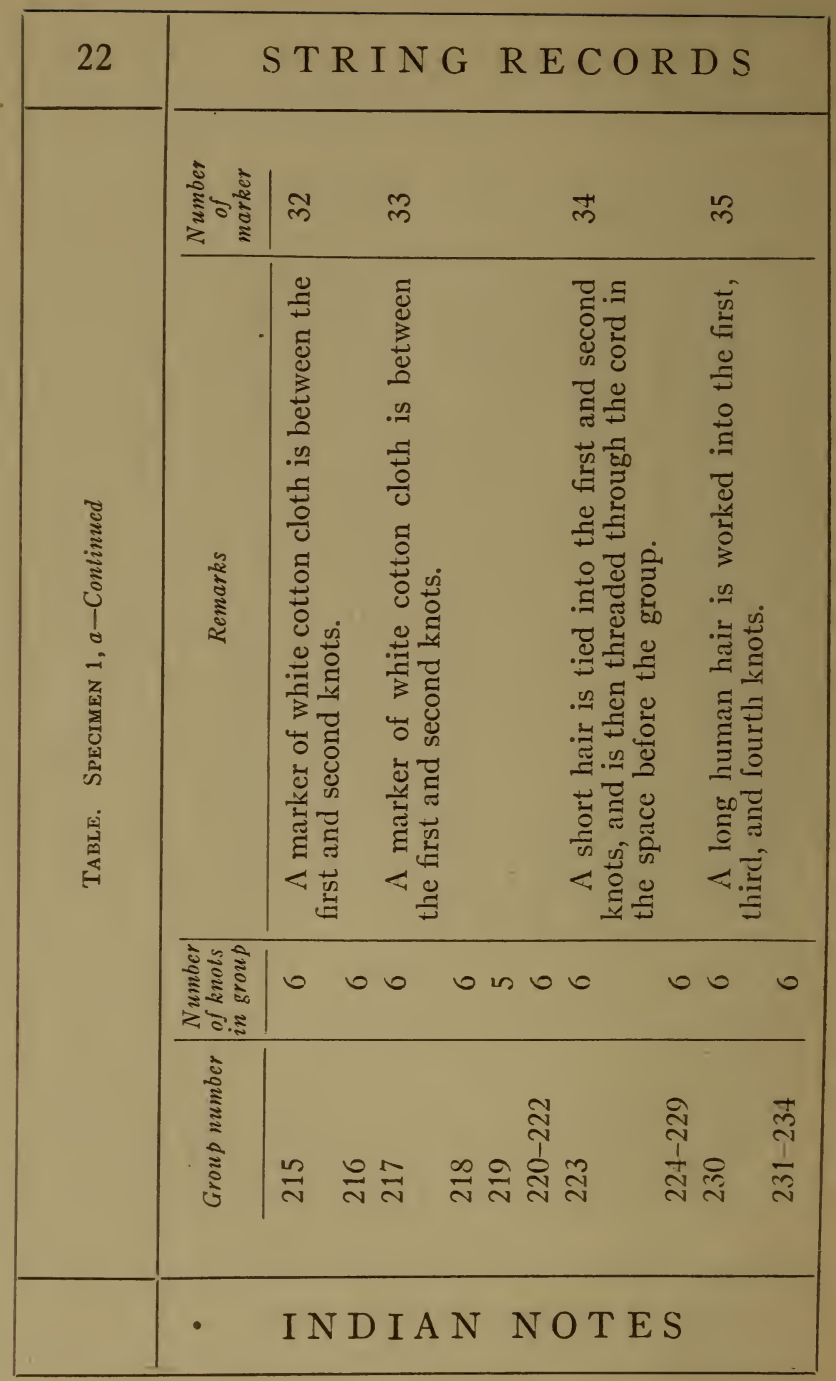




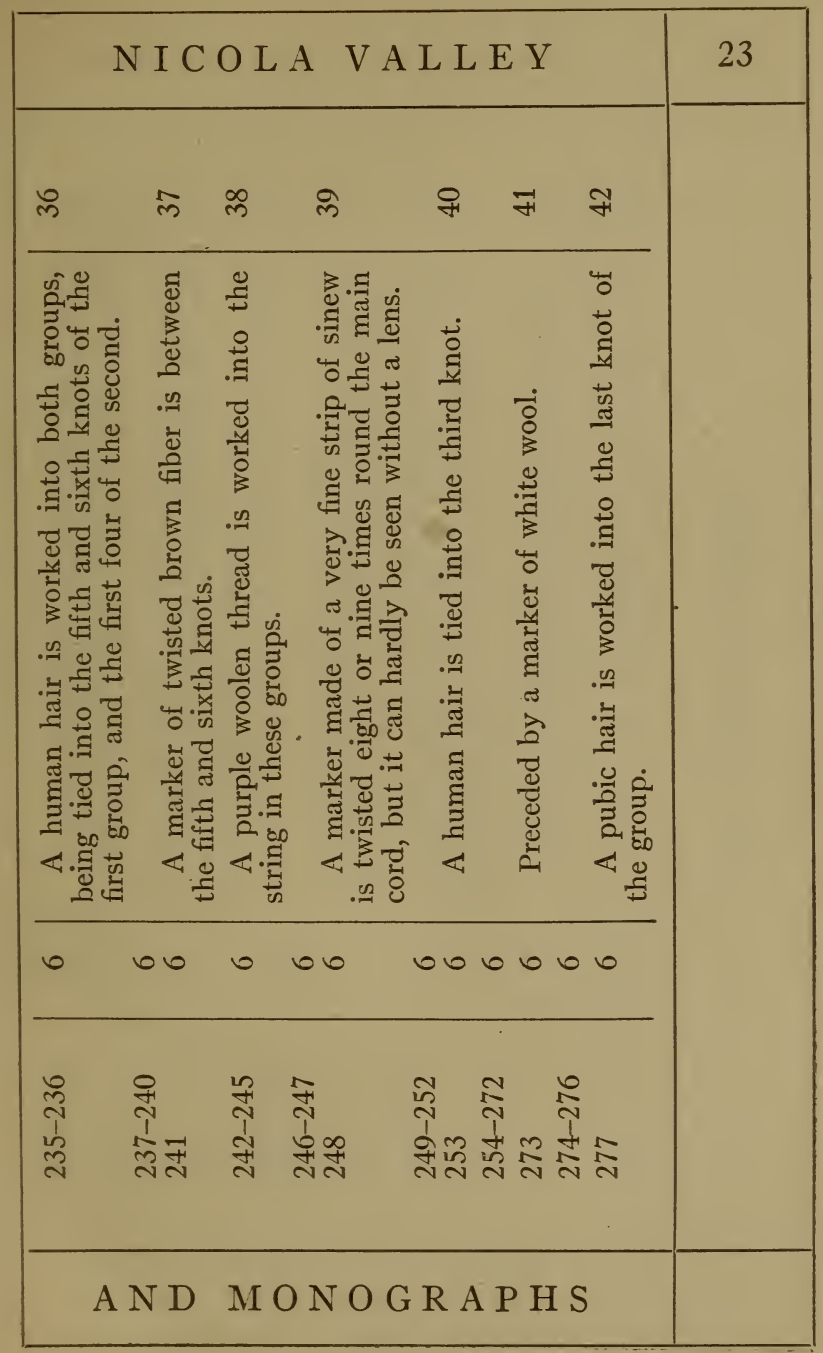




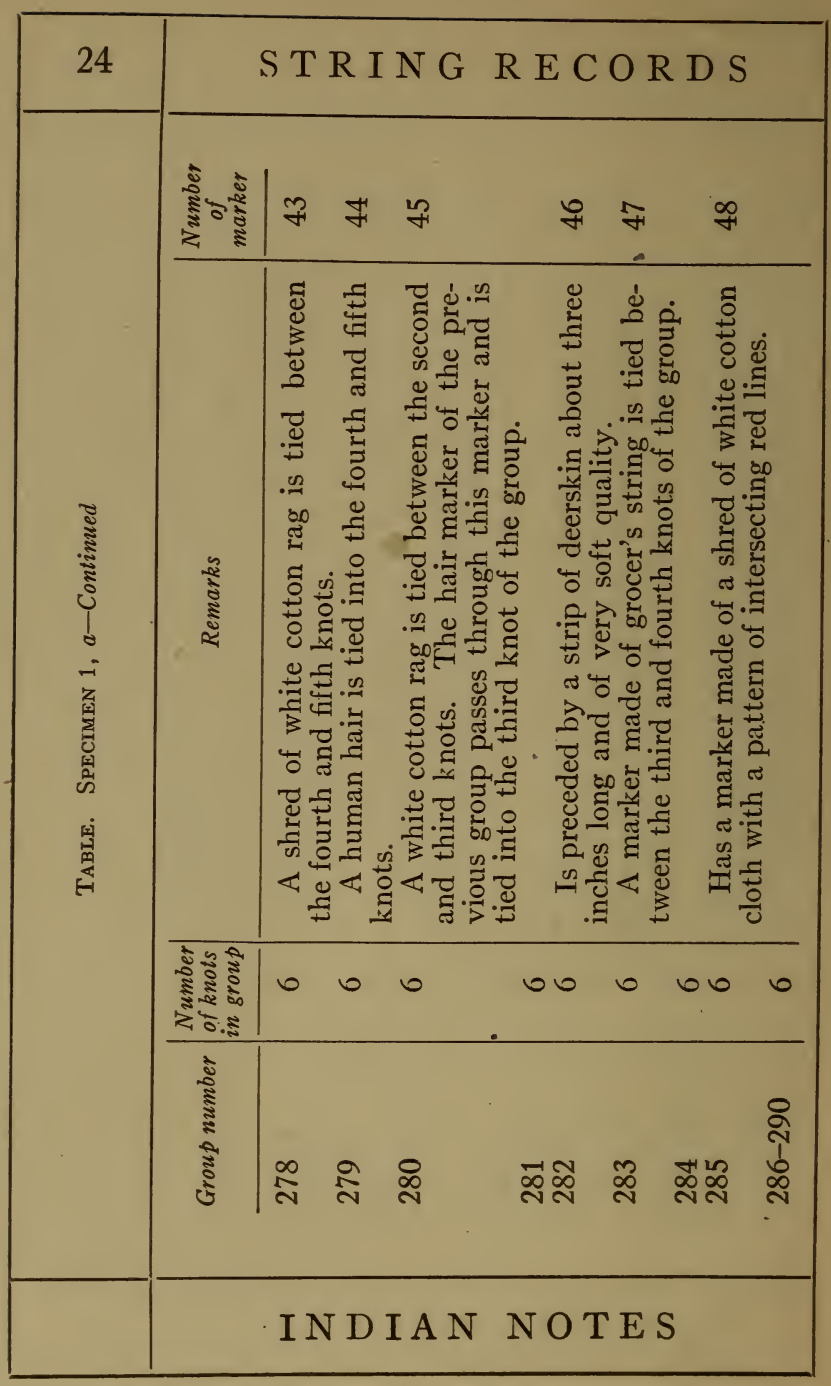




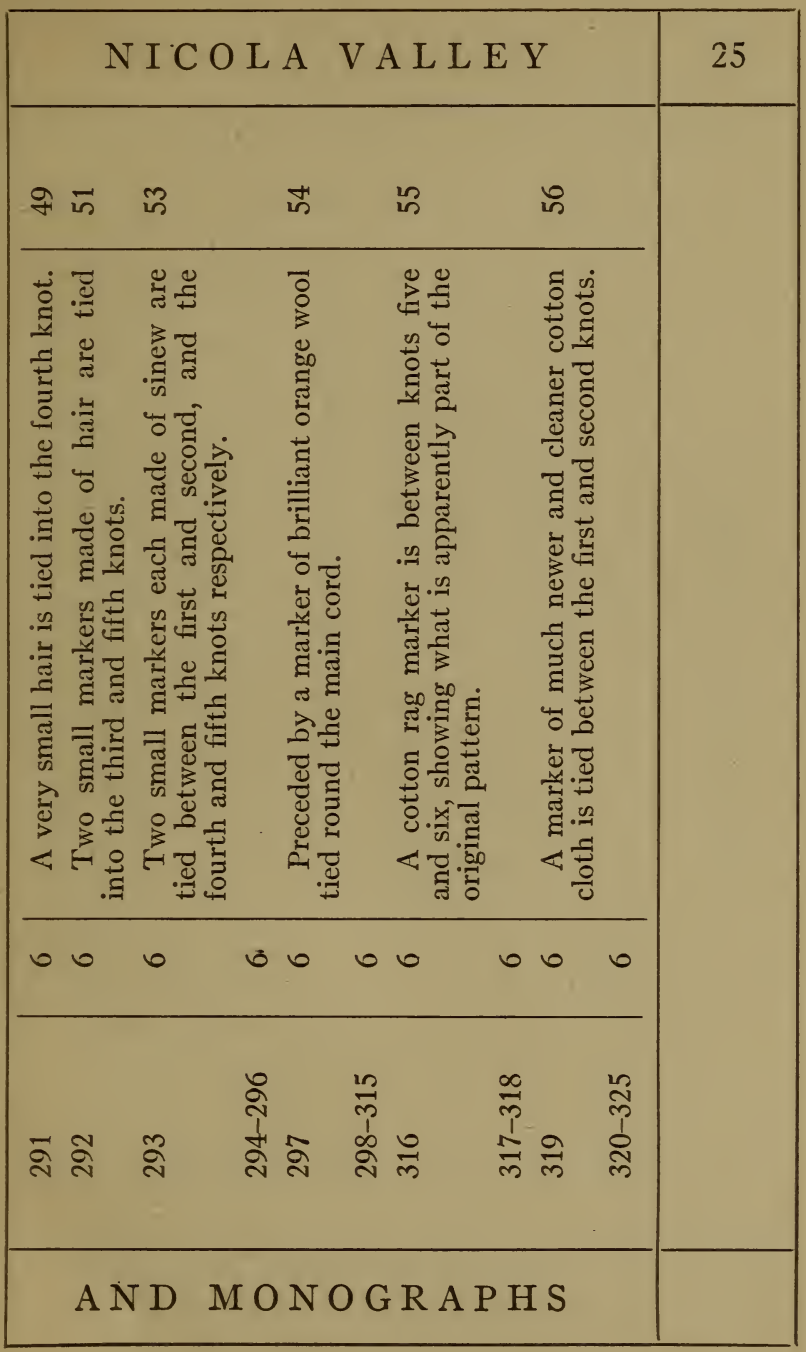




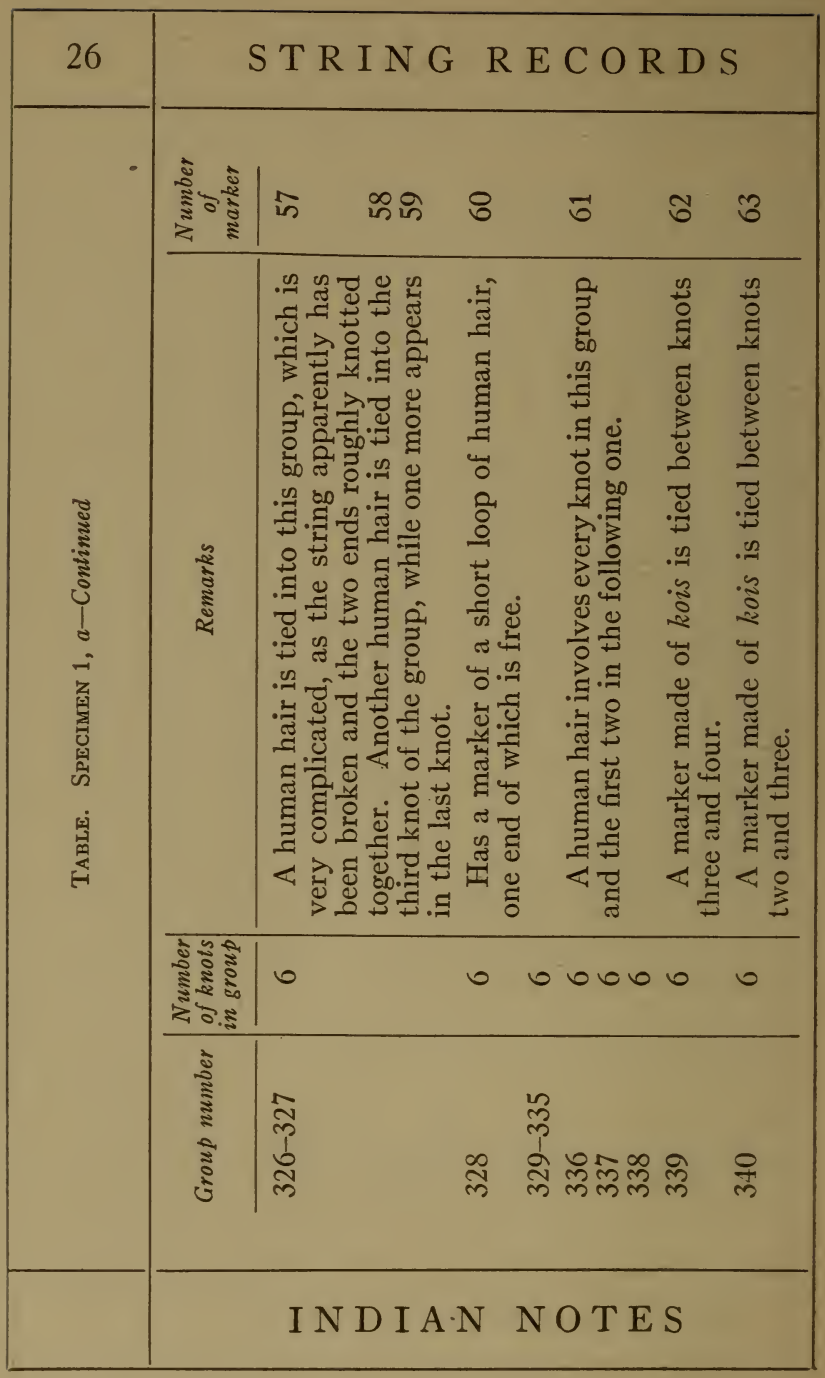




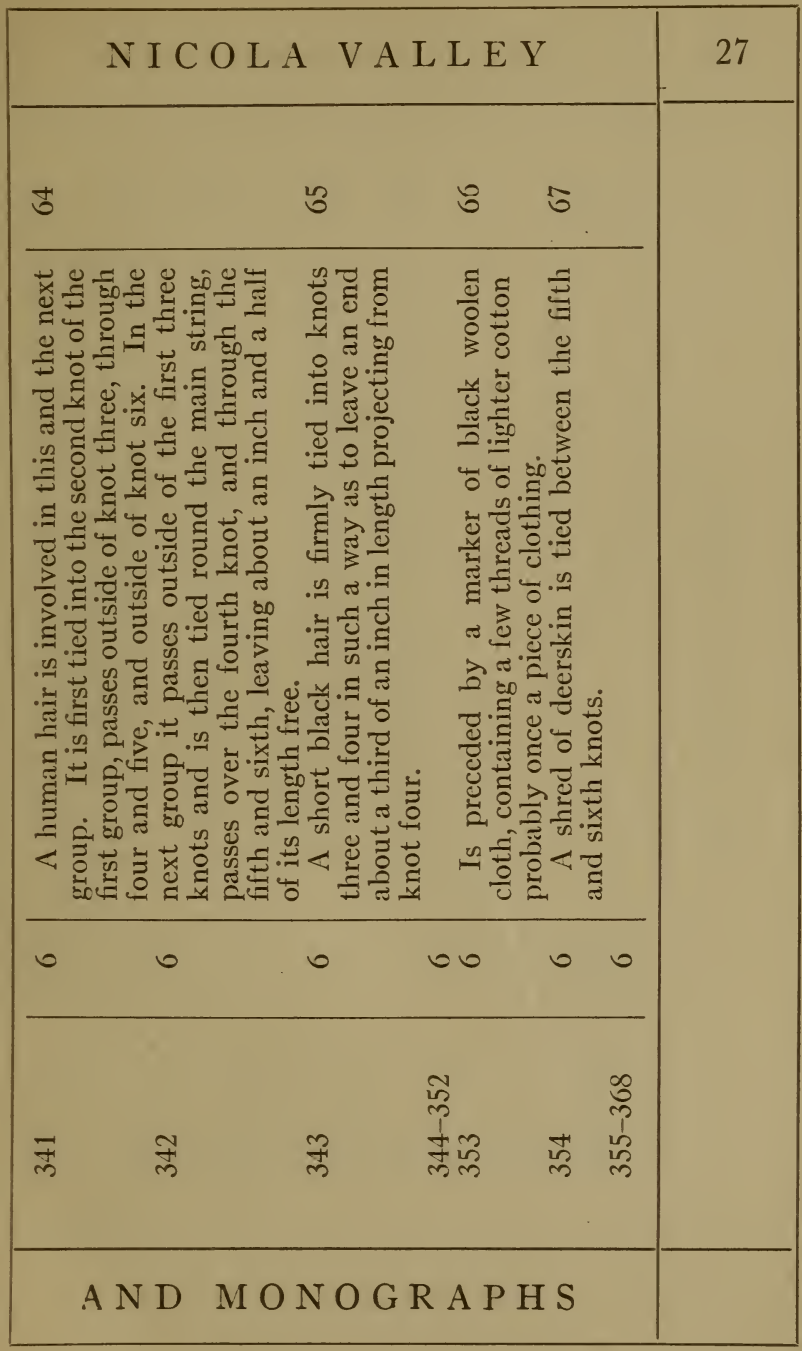




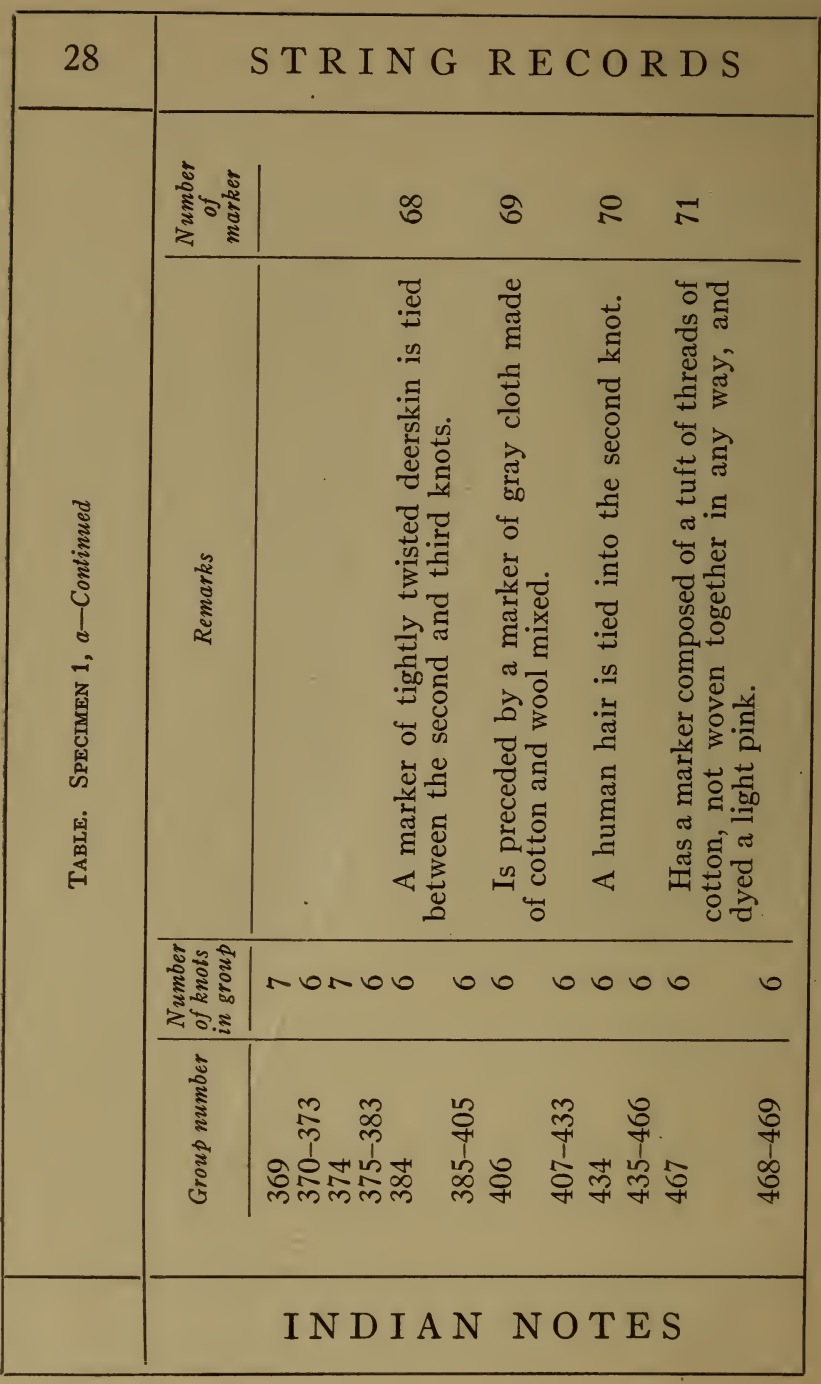




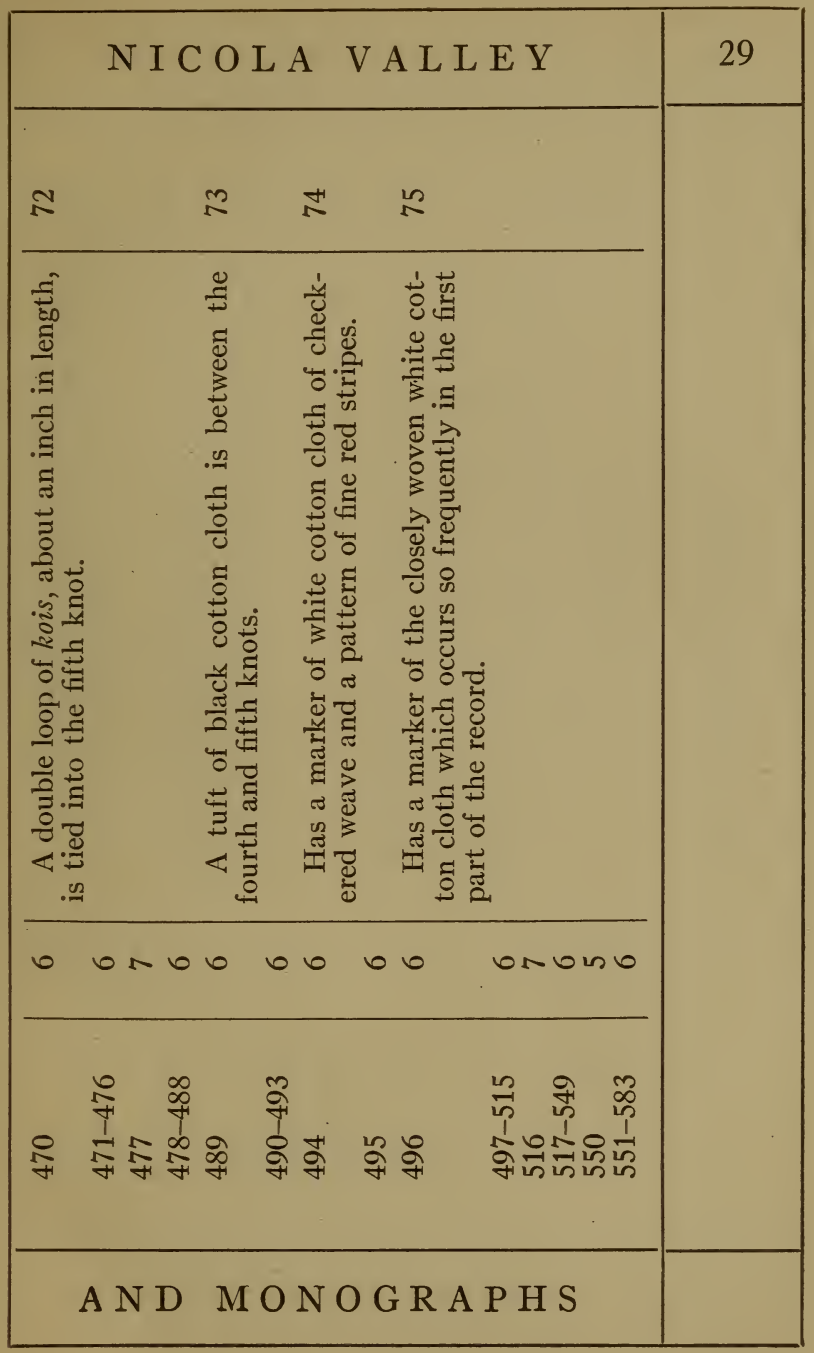




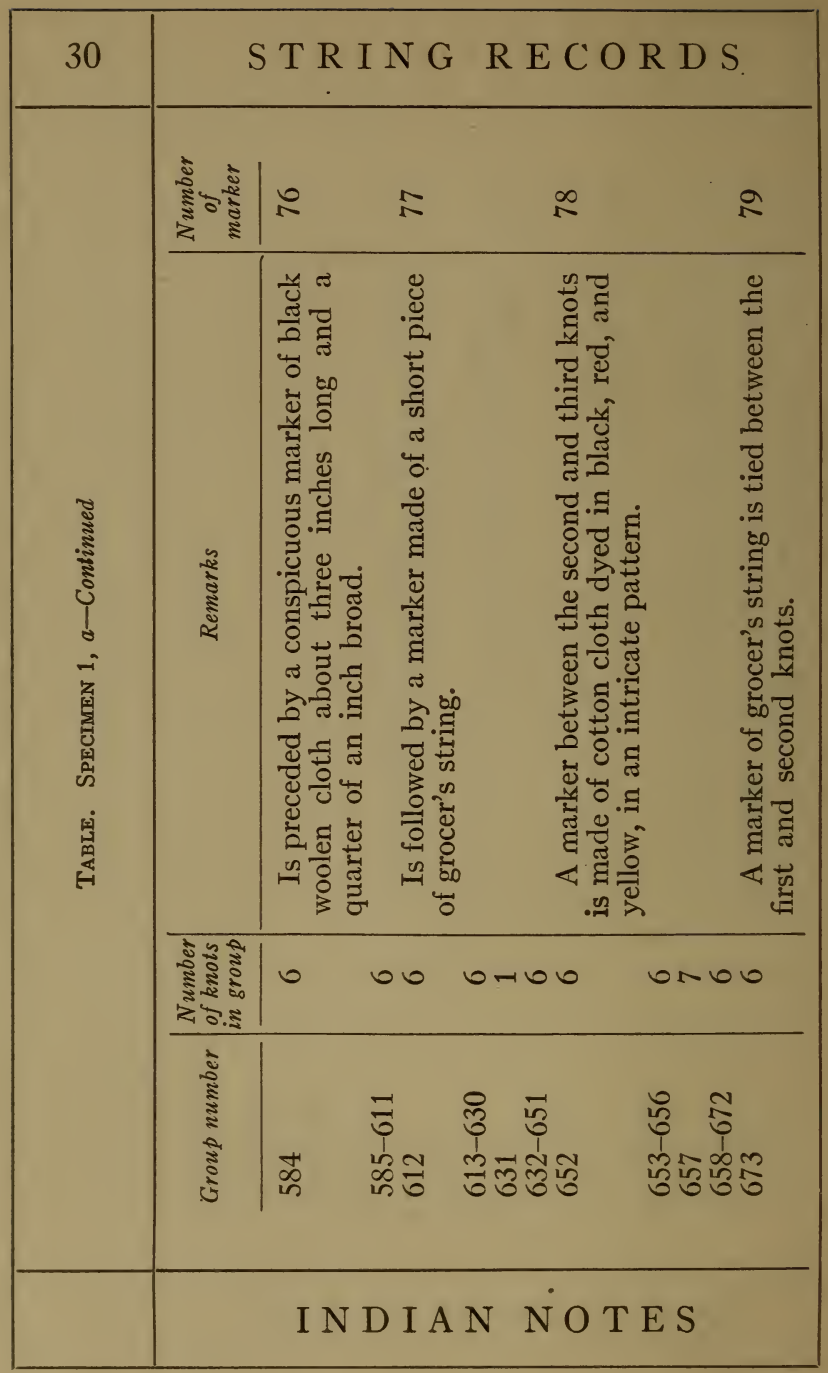




\section{N I C O L A V A L E Y}

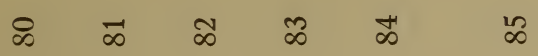

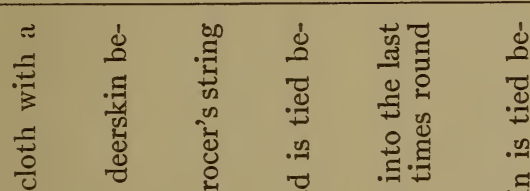

苍 尊

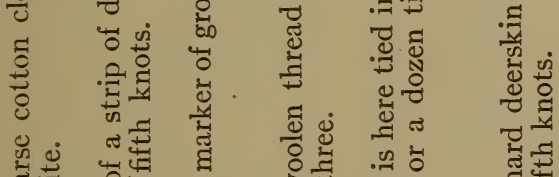

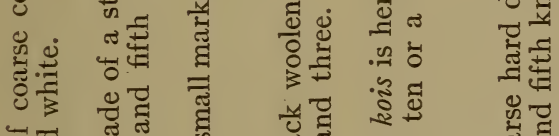

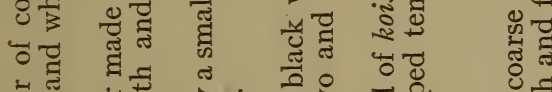

t)

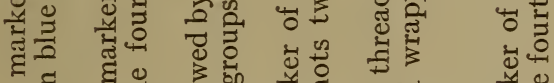

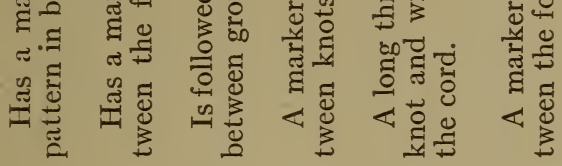

000000 on 00 o

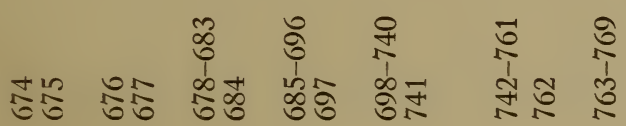

\section{A N D MONOGRAPHS}




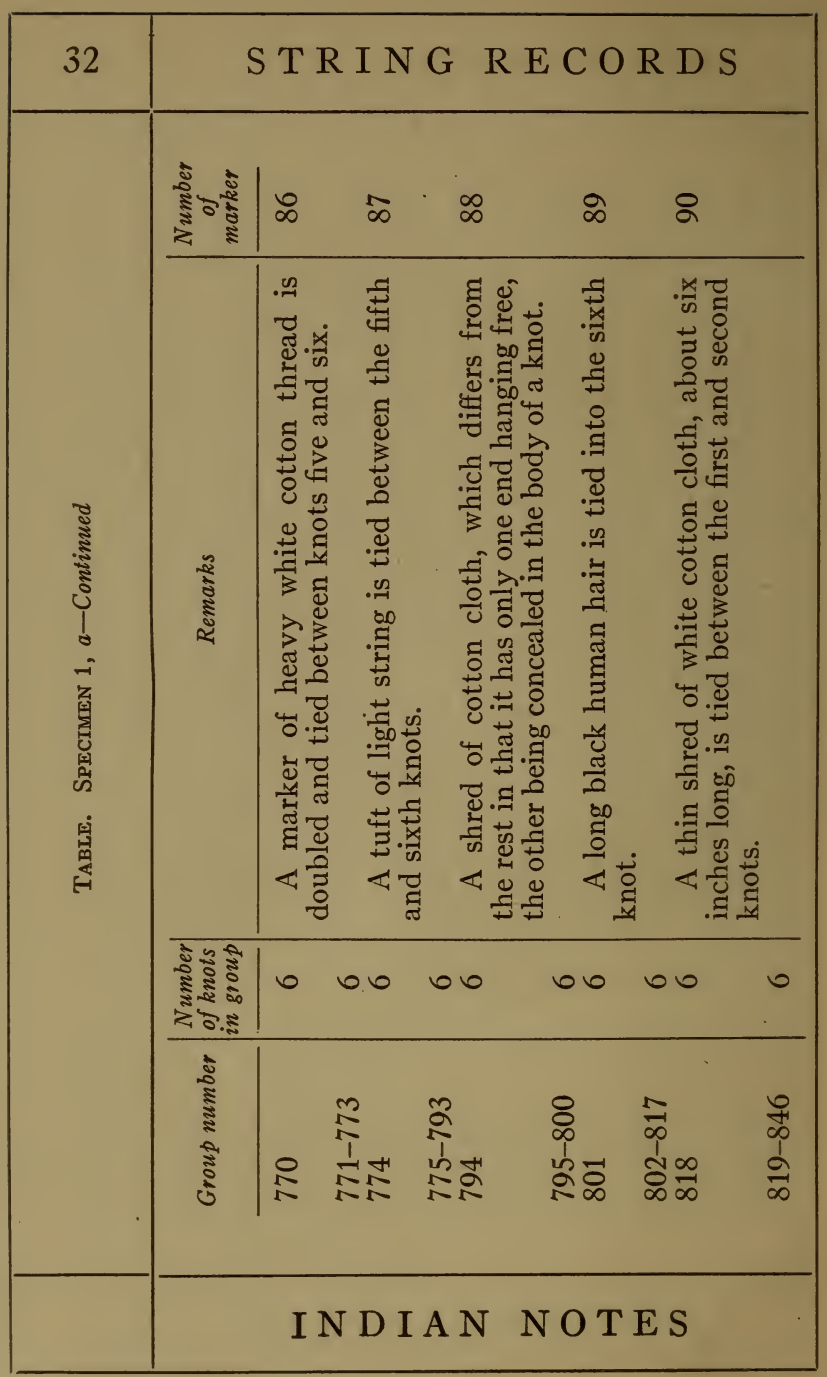




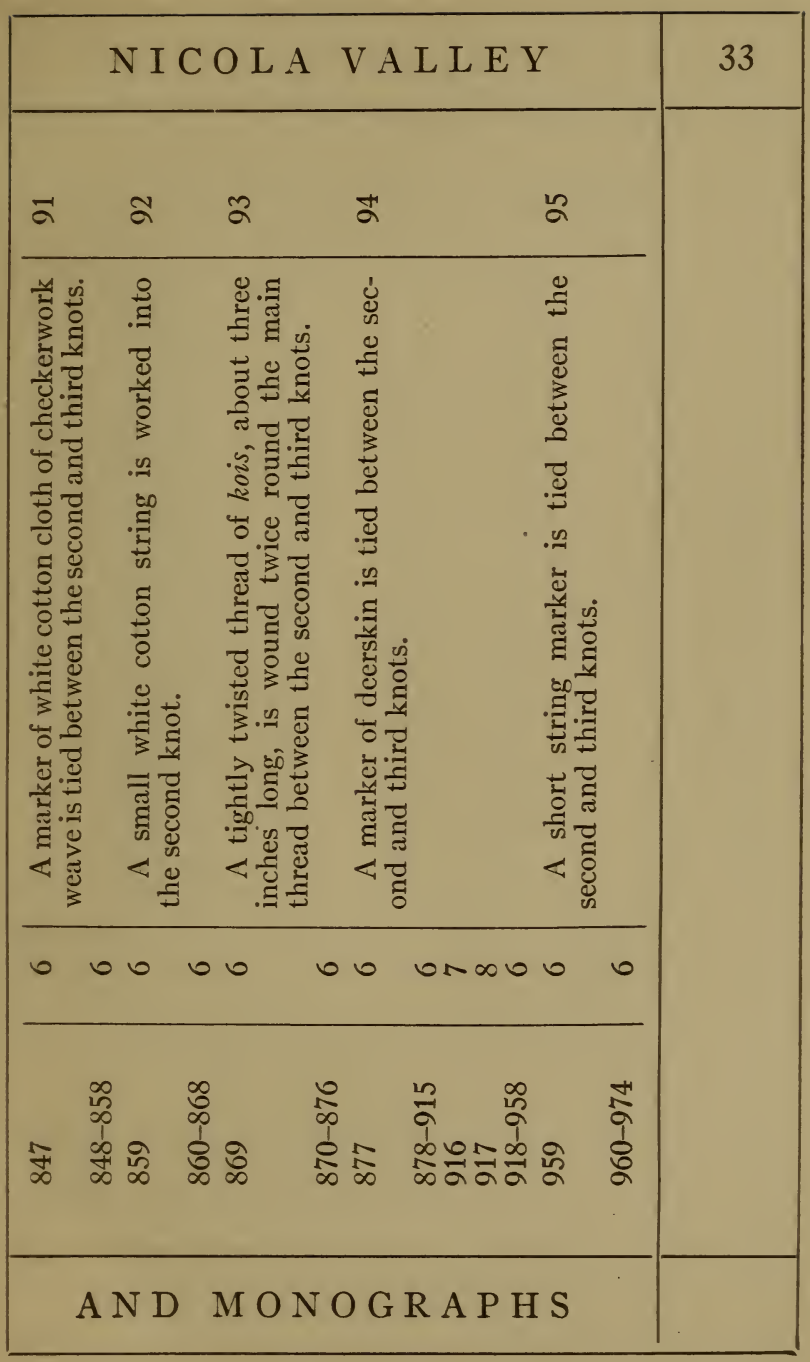




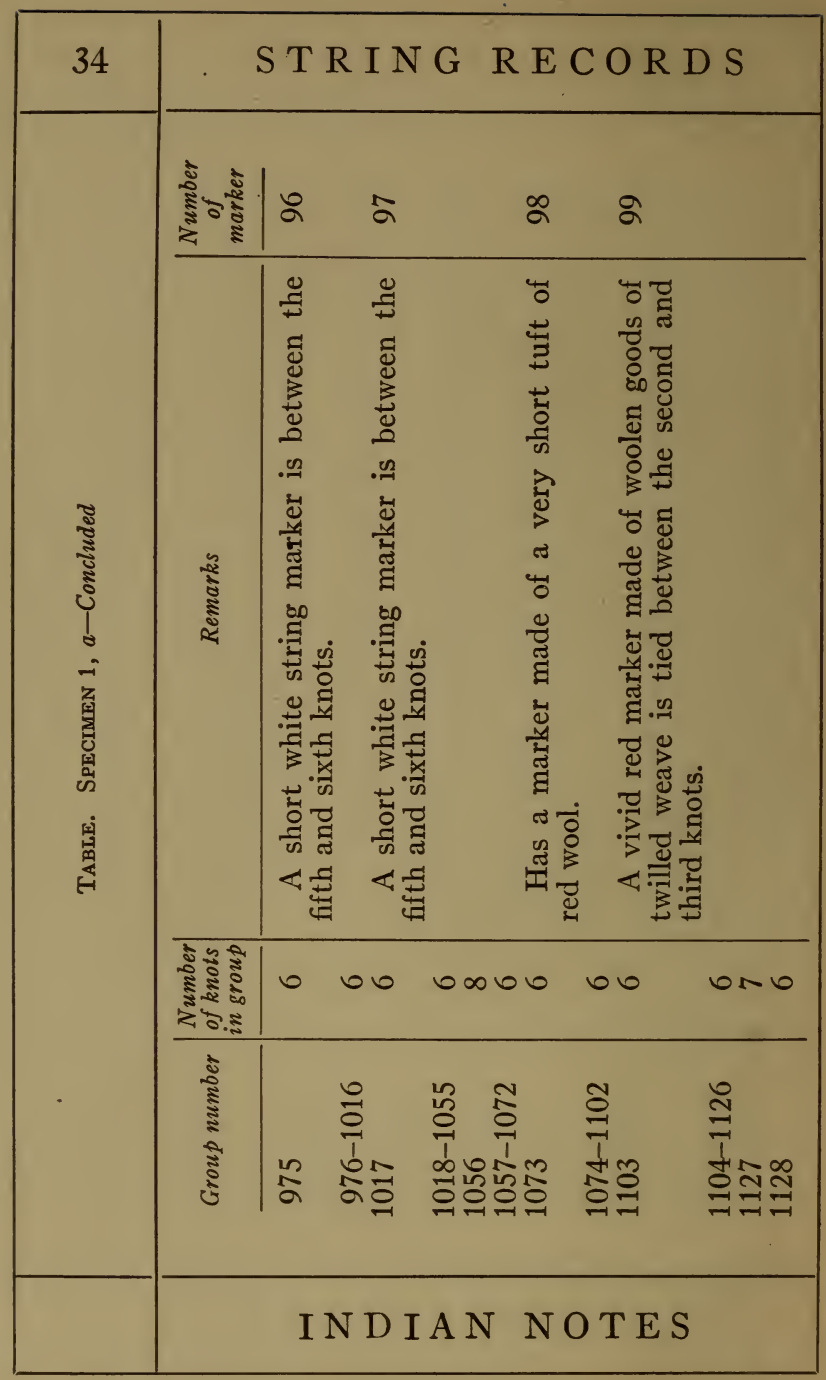




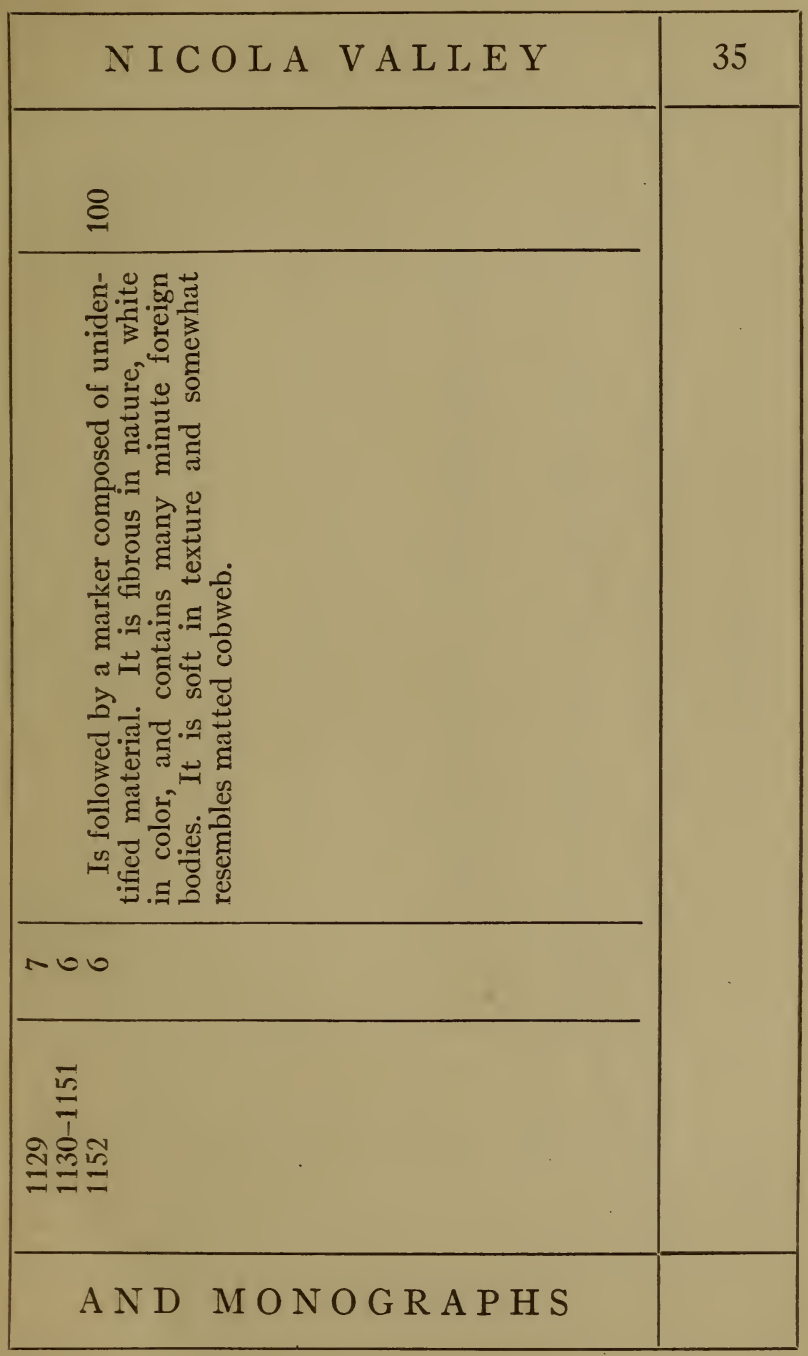




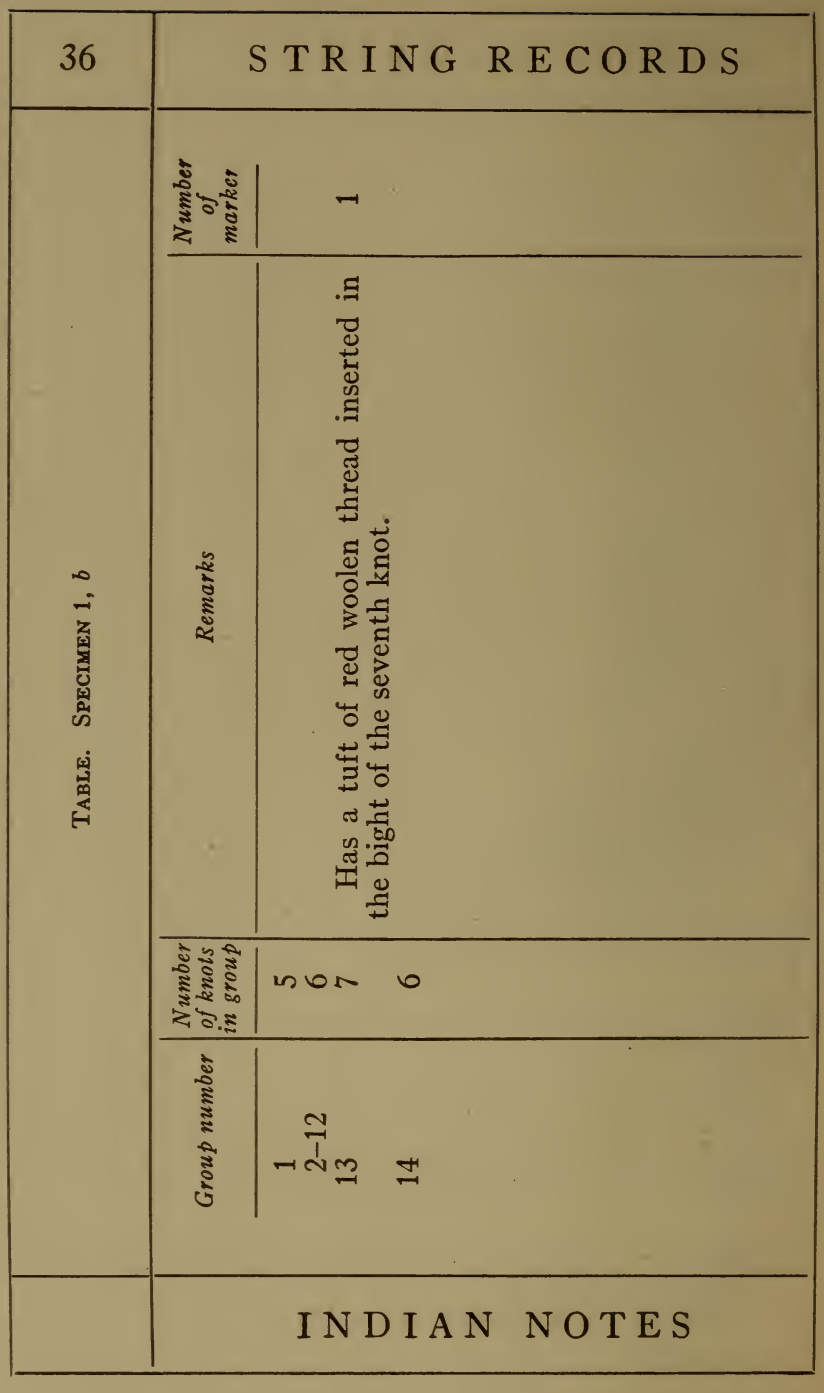




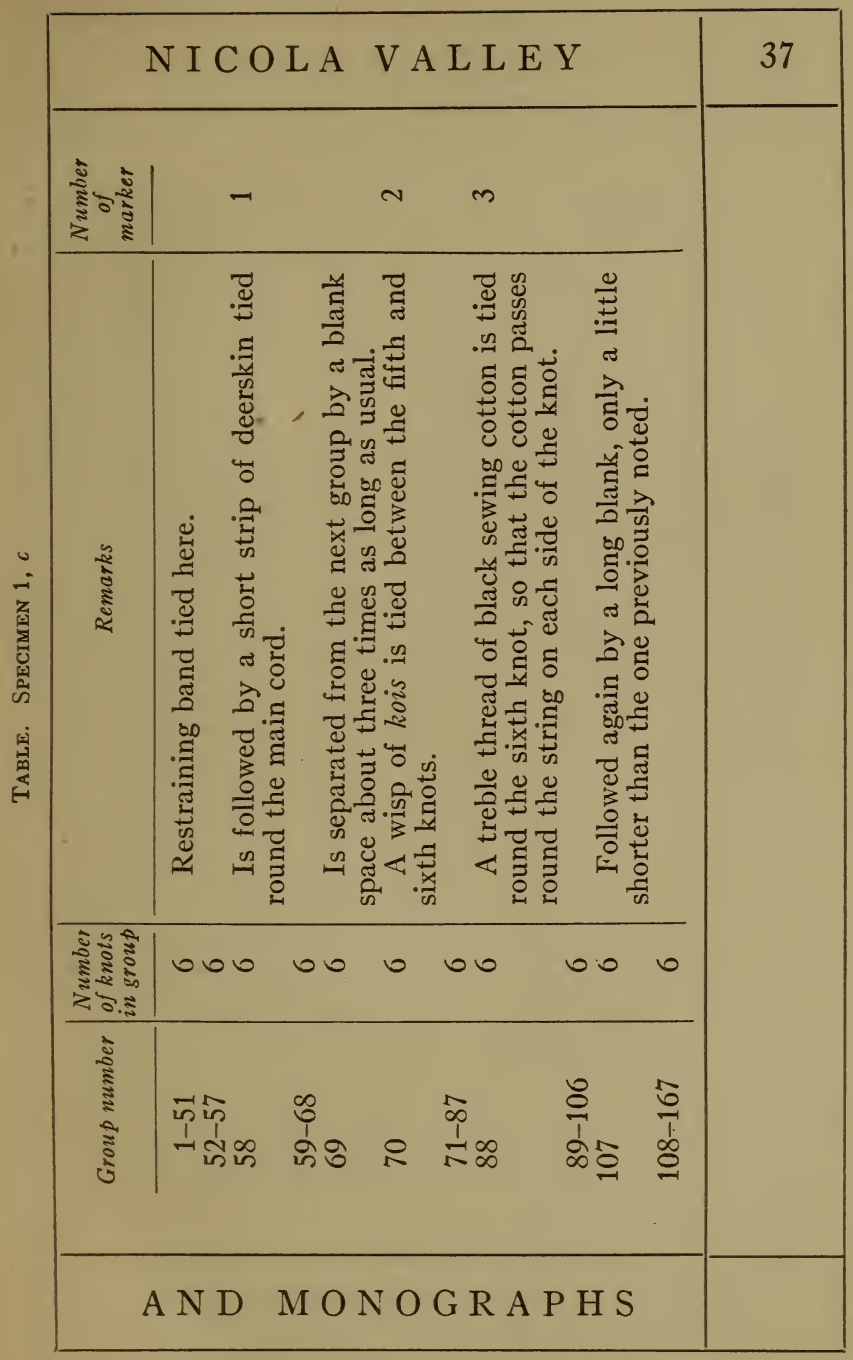




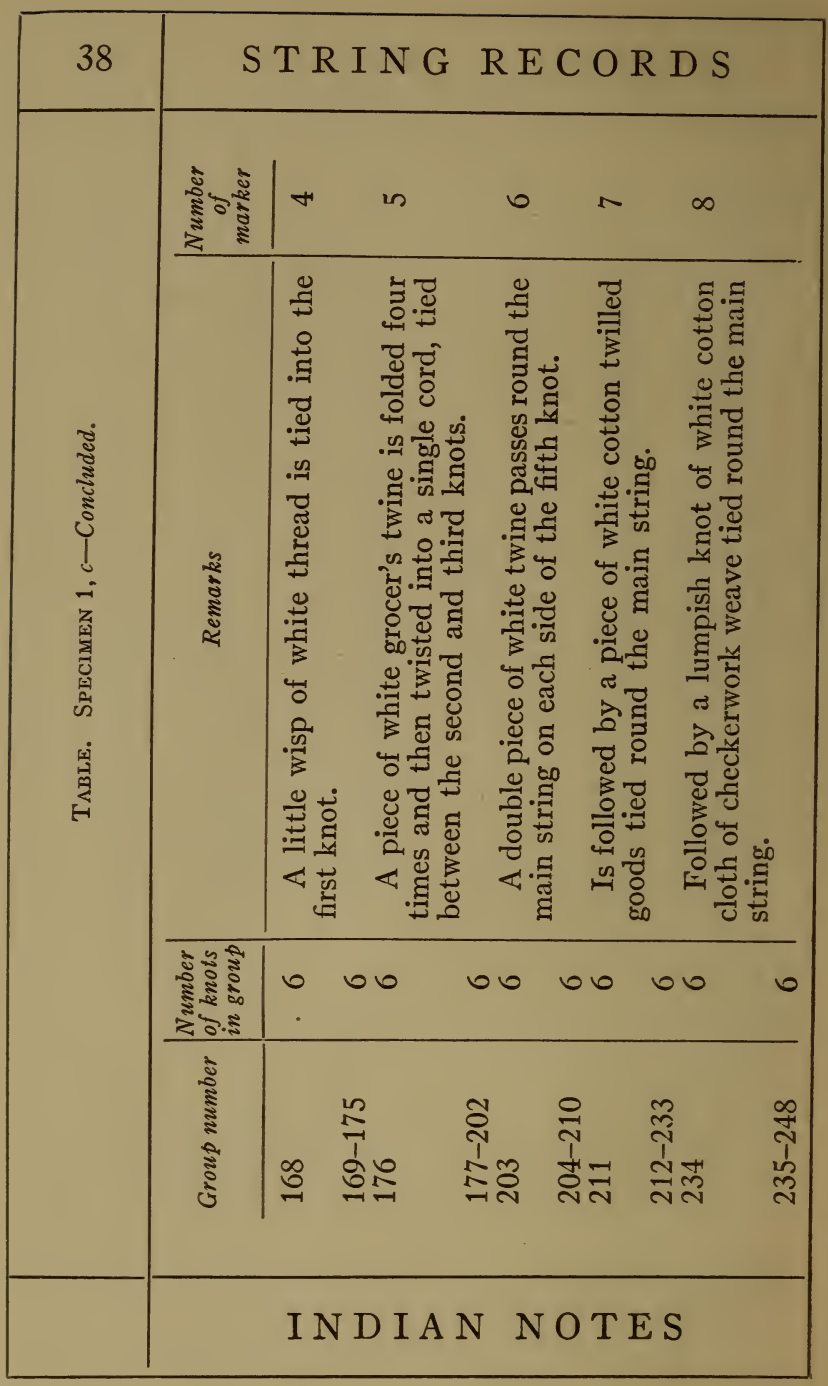




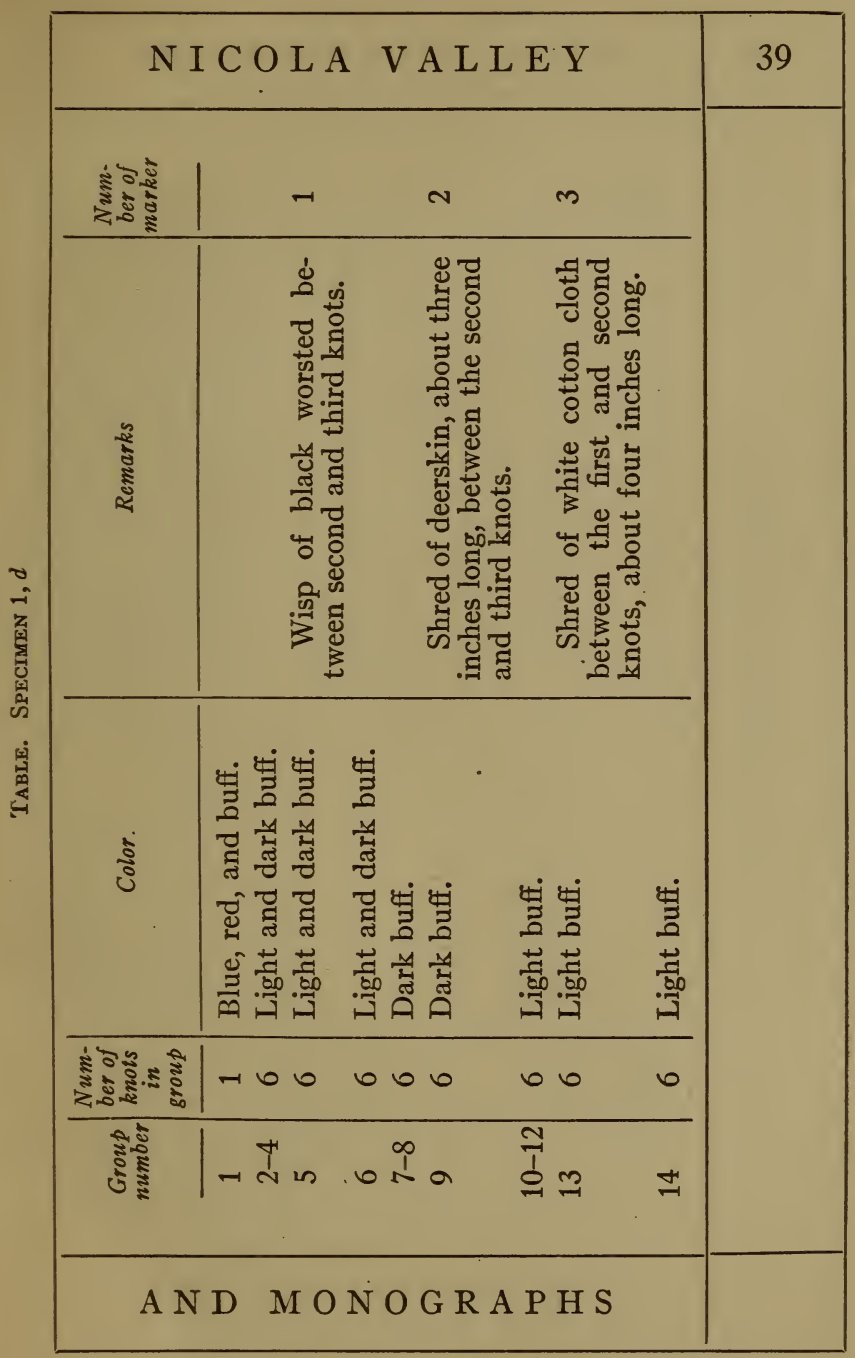




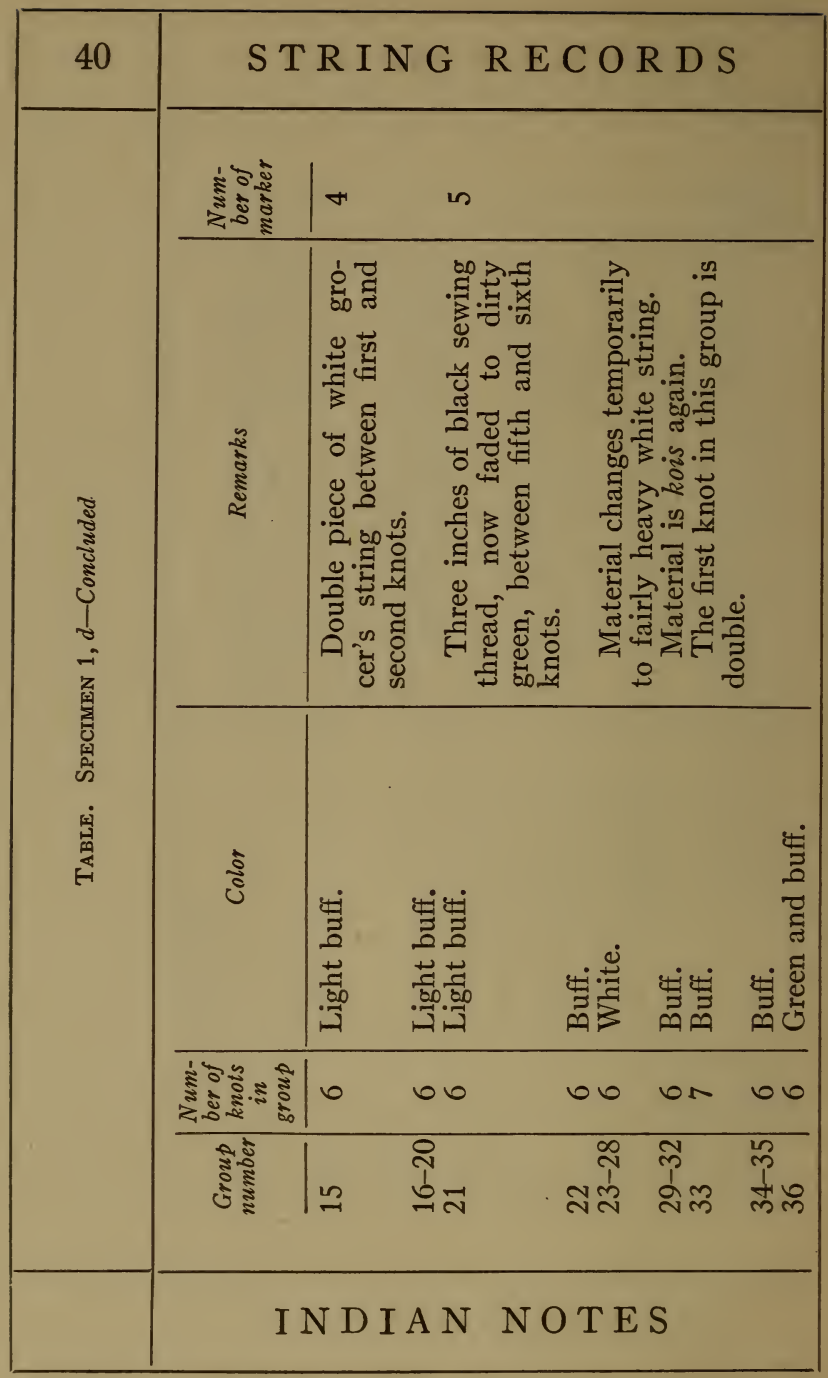




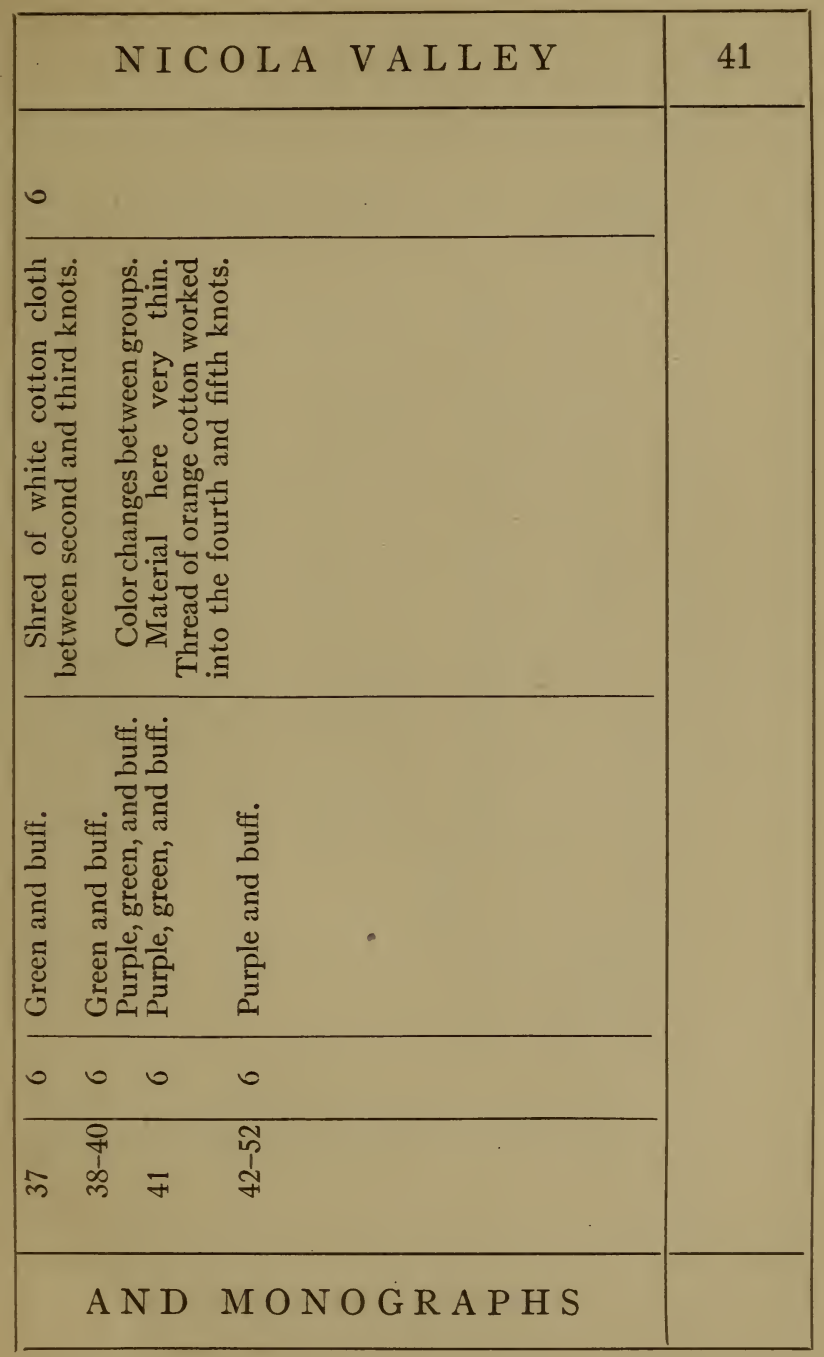




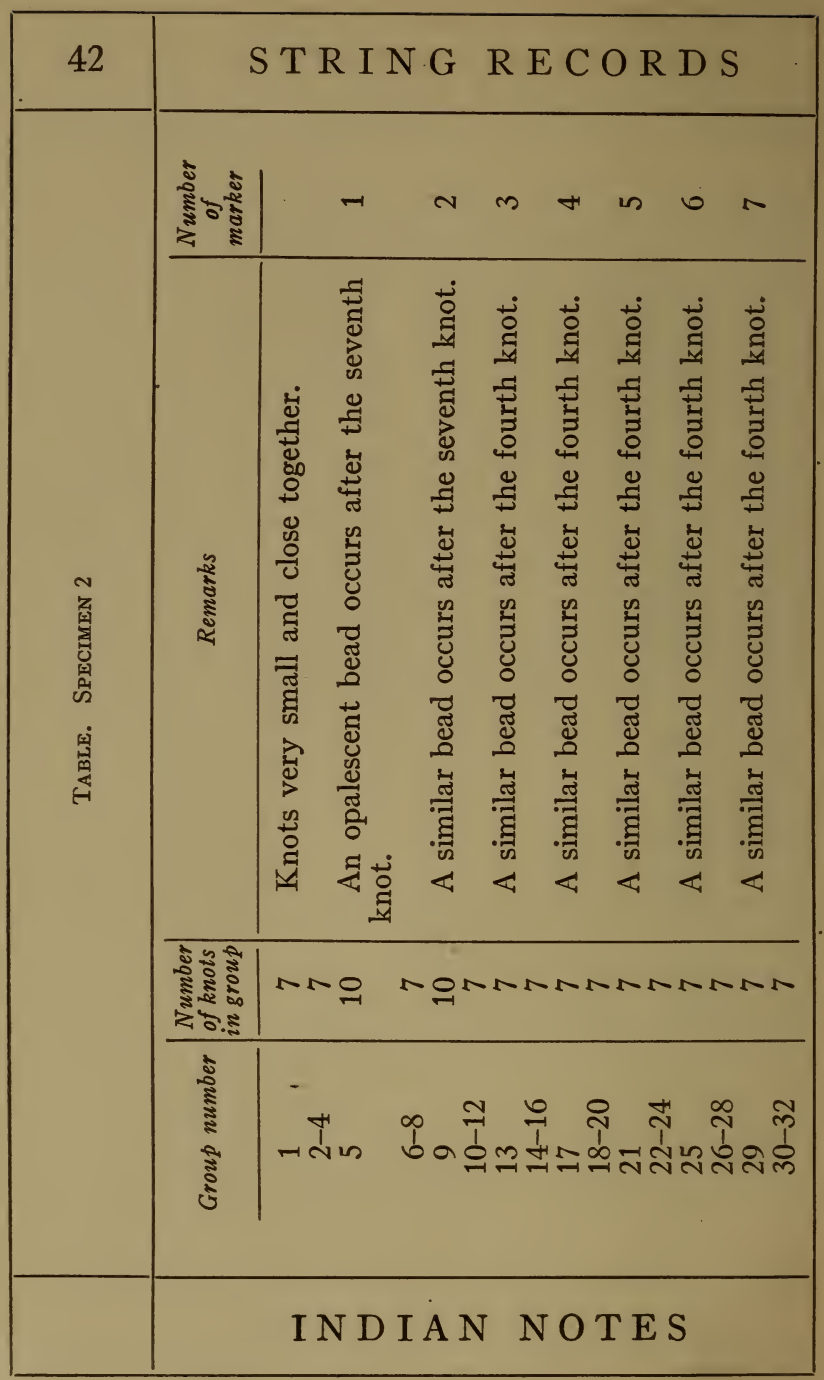




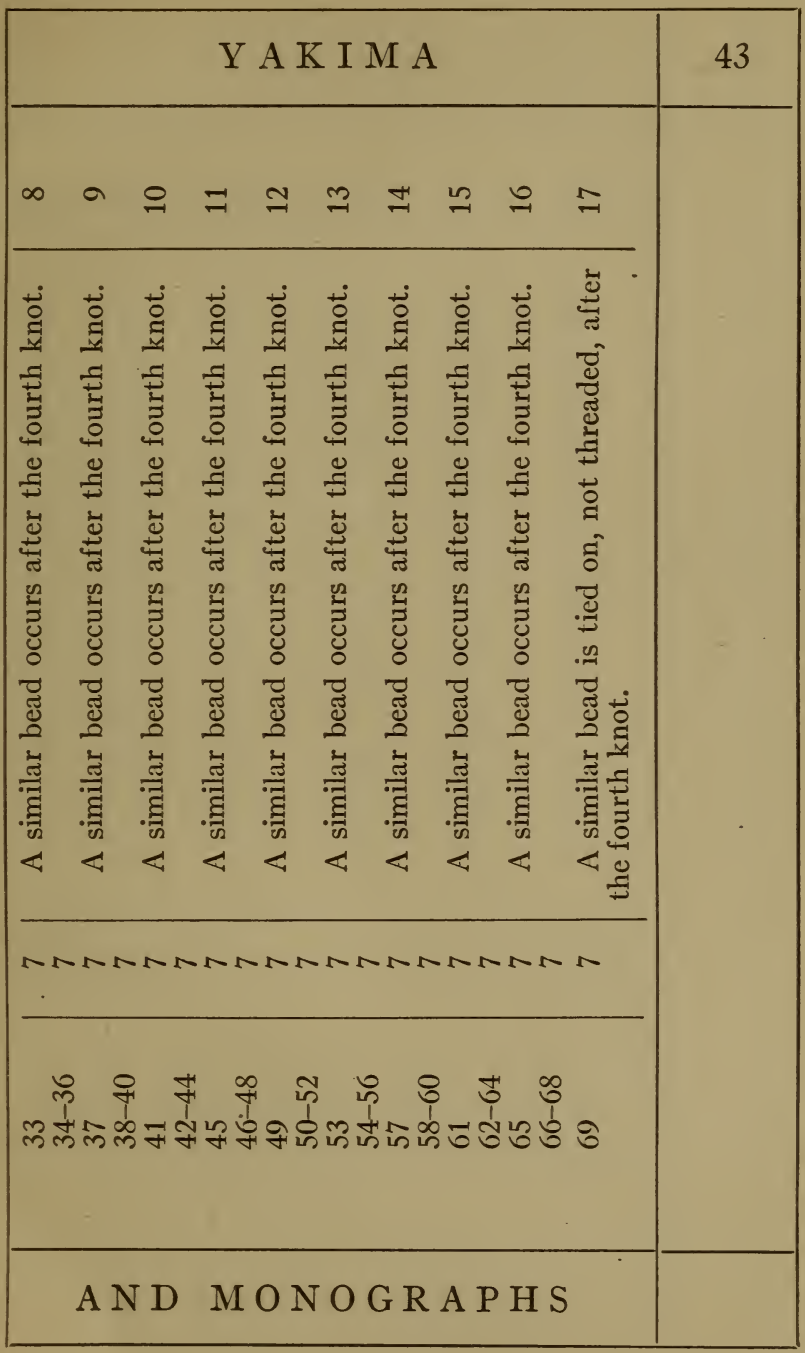




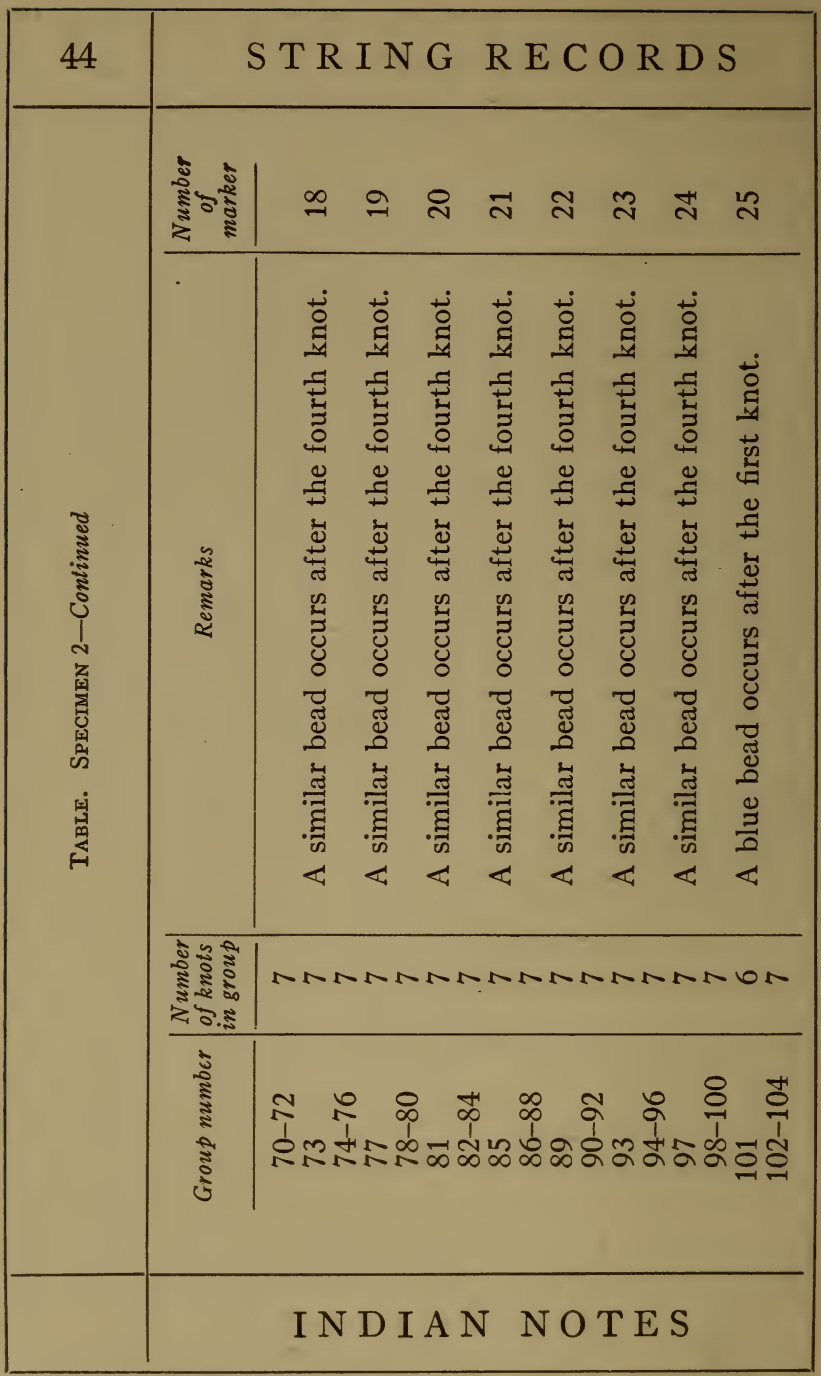




\section{Y A K I M A}

\begin{tabular}{|c|c|c|c|c|c|c|}
\hline 워 & $\hat{\sim}$ & $\stackrel{\infty}{\sim}$ & શิ & ల్లి & $\bar{m}$ & ๗ె \\
\hline 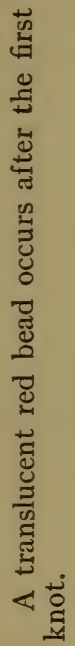 & 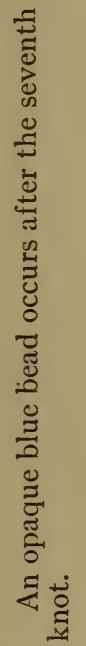 & 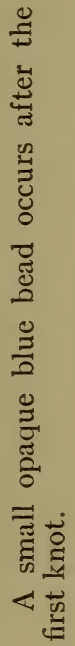 & 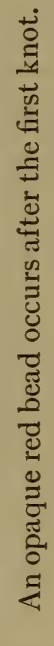 & 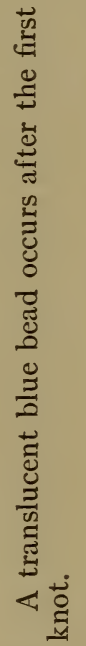 & 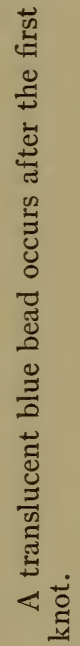 & 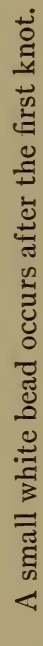 \\
\hline
\end{tabular}

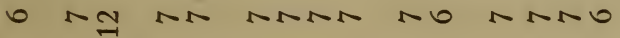

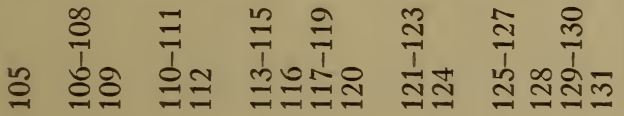

\section{A N M M NOGRAPHS}




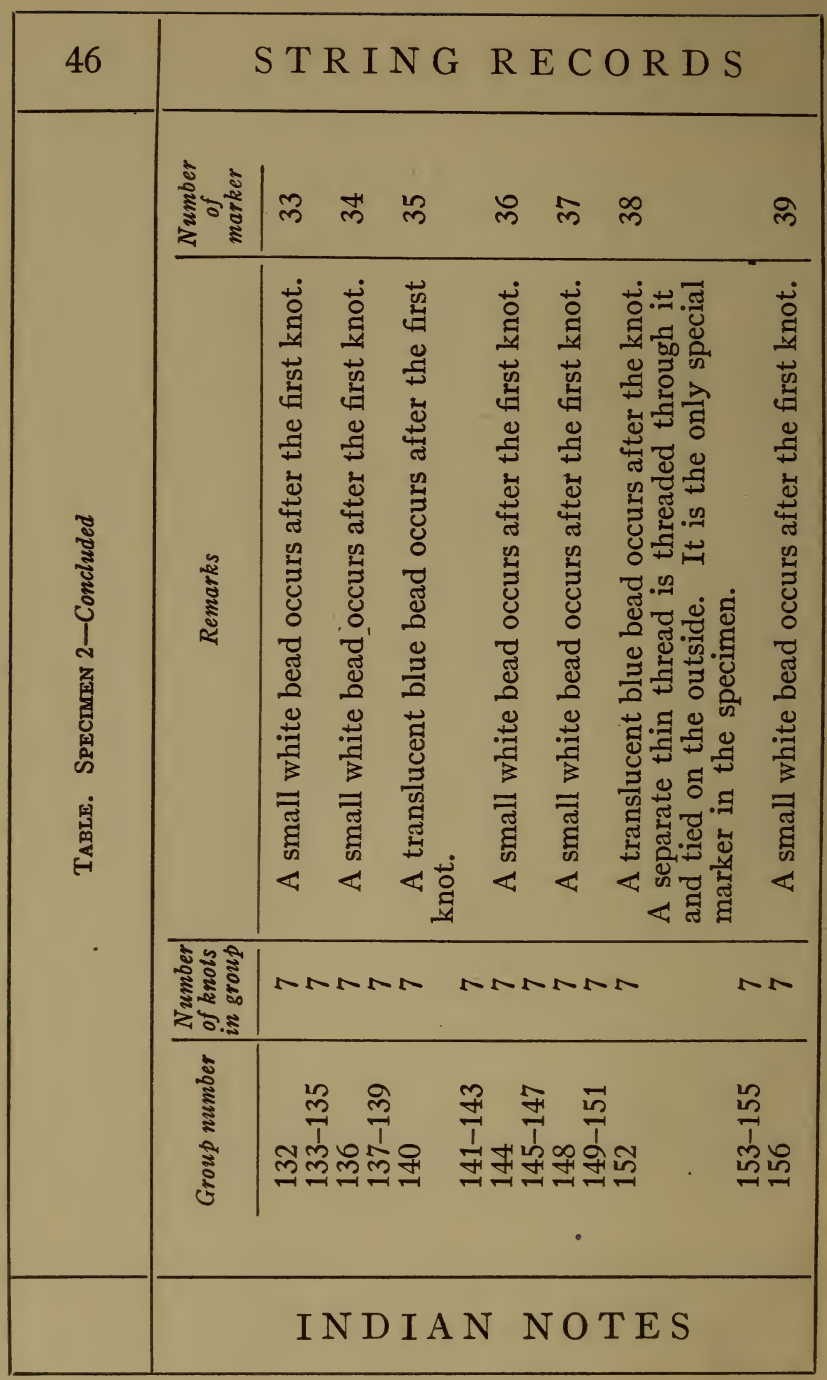




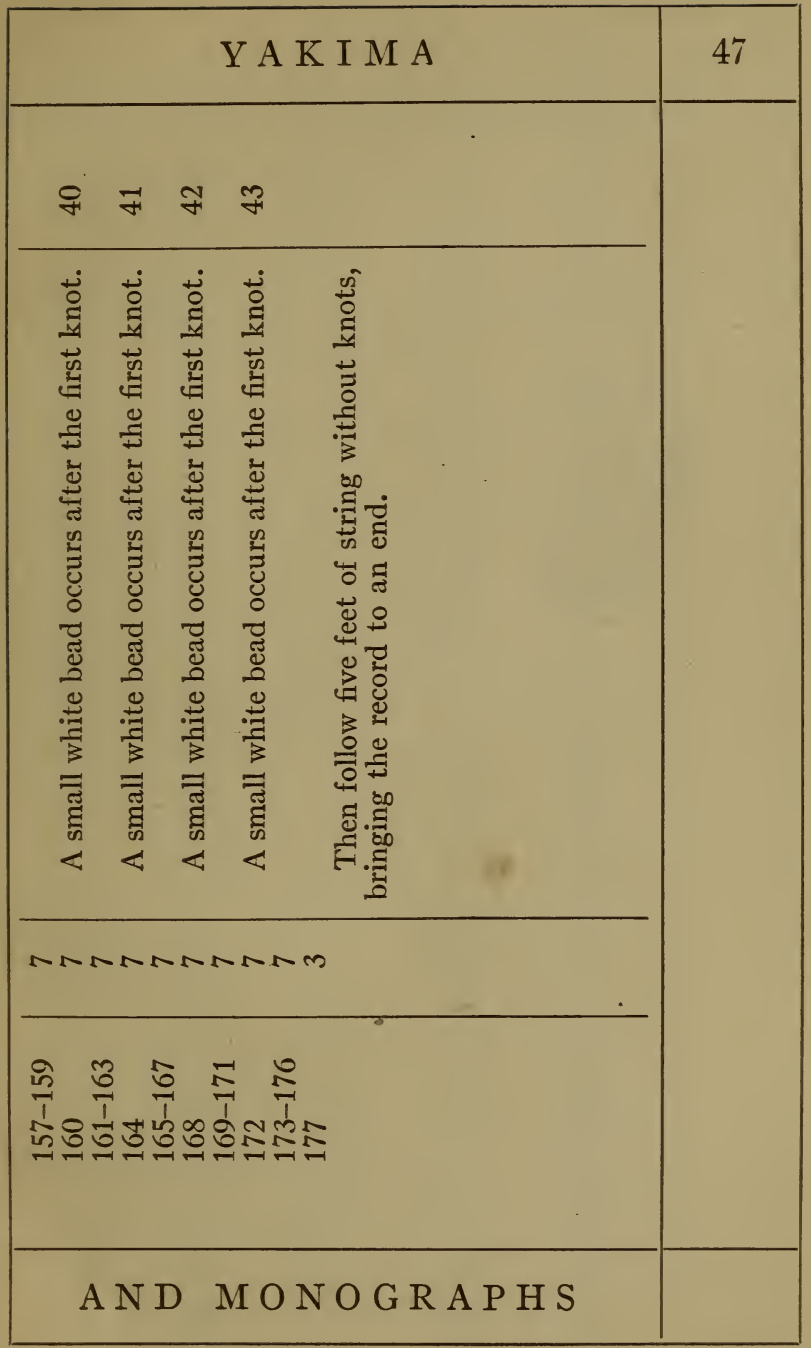




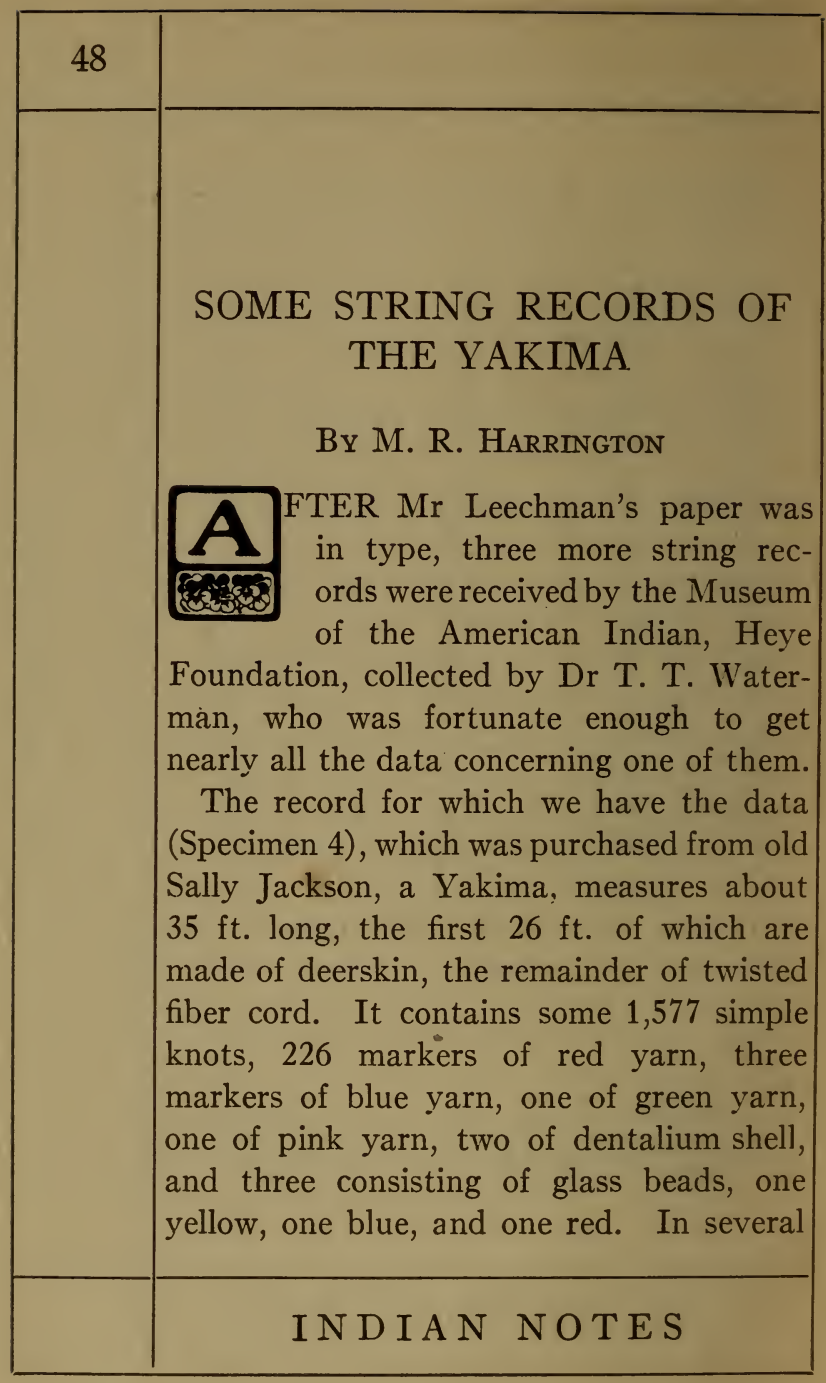




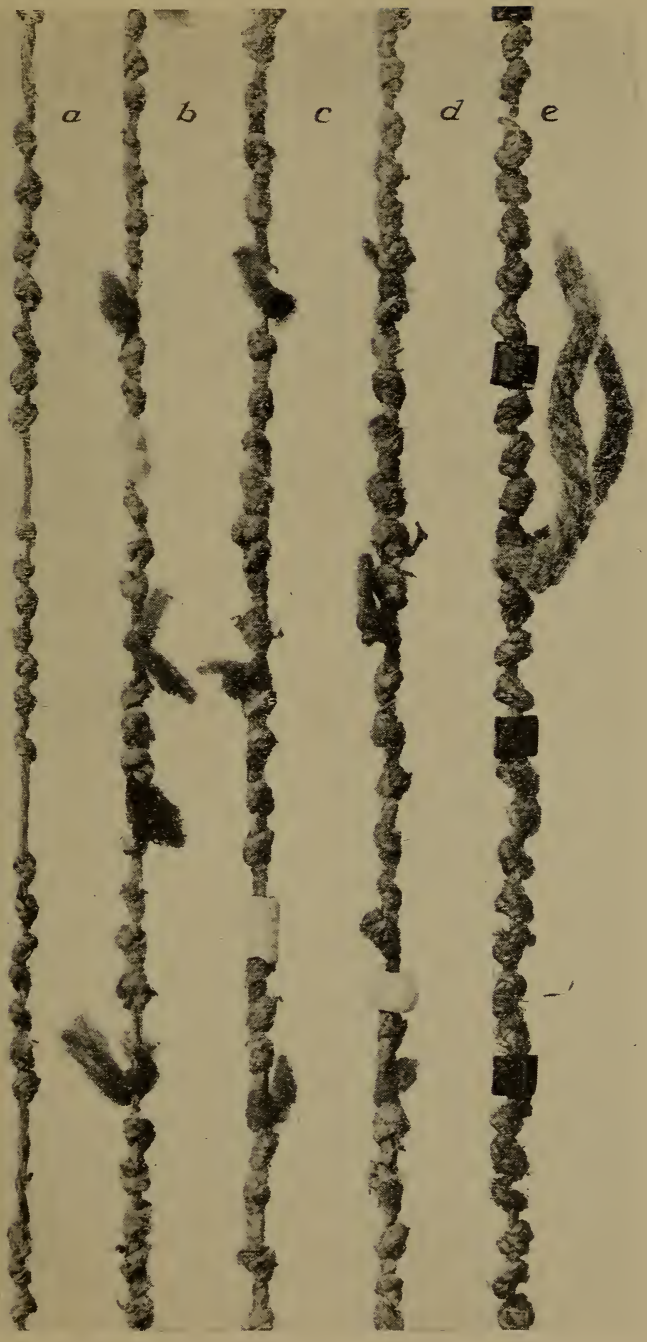

TYPICAL SECTIONS OF STRING RECORDS 4 AND 6 , YAKIMA, WASHINGTON

(Length of sections, 5.5 in.) 



\section{Y A K I M A}

places a single black human hair is caught in a knot, but this is perhaps accidental, as no explanation of them was given.

Mrs Jackson commenced the record on the death of her husband, apparently for the sole purpose of keeping tally of the dates of deaths among her family, for no other events are recorded. Nights are represented by plain knots arranged in groups of seven, with considerable precision except at the very first, and after every seventh knot is a piece of red yarn tied on to represent Sunday, while the other markers represent the deaths as they occurred (pl. vi, $b, c, d$.).

The first red marker, however, records the death of her husband, "Old Jackson;" then come five knots, and then another red marker, this one representing Sunday, as do all of this color thereafter.

One week after the loss of her husband, one of her sons also passed away, which sad event is recorded by a piece of blue yarn tied between the second and third knots, by which we may infer that he died on a Tuesday. His loss seems to have con-

\section{A ND MONOGRAPHS}




\begin{tabular}{|c|c|}
\hline 50 & \multicolumn{1}{|c|}{ S T R I N G R E C O R D S } \\
\hline $\begin{array}{l}\text { fused her to such an extent that she gives } \\
\text { nine instead of seven nights to the week of } \\
\text { his death, but thereafter the knots appear } \\
\text { in groups of seven with strict regularity. } \\
\text { After the twenty-third red marker fol- } \\
\text { lowing Jackson's death in the record, or } \\
\text { twenty-three weeks later, occurred the death } \\
\text { of one of Sally's grandchildren, represented } \\
\text { by a bead of dentalium shell about } 0.2 \text { in. } \\
\text { long, which seems to have taken place on } \\
\text { Monday, because the bead is strung on the } \\
\text { thong between the first and second knots. } \\
\text { A little more than a year after the old man } \\
\text { died,-the day after the 56th Sunday, to } \\
\text { be exact,-a large yellow glass bead (pl. } \\
\text { vi, a) represents the death of Sally's mother; } \\
\text { while on the Wednesday after the eighty- } \\
\text { second Sunday a second short piece of den- } \\
\text { talium shell records the loss of another } \\
\text { grandchild (pl. vi, c). } \\
\text { Sally's sister died on the 99th Monday, } \\
\text { according to the record, as shown by a piece } \\
\text { of blue yarn tied between the first and sec- } \\
\text { ond knots following the ninety-ninth red } \\
\text { marker; and a few weeks later, the Friday } \\
\text { following the 104th Sunday,-as shown by }\end{array}$ \\
\hline I N D I A N N O T E S \\
\hline
\end{tabular}




\section{Y A K I M A}

a blue bead,- - she lost another grandchild, the last relative she had left in the vicinity of her home.

More than a year then passed without further bereavement, but then a piece of green yarn, tied between the fifth and sixth knots following the 164th red marker, tells of the death of another son, at Pendleton, Oregon.

For ten weeks Sally had a respite from bad news; but on the Friday after the 174th Sunday following her husband's decease, news reached her of the death of her sister's daughter on Yakima river, and this was recorded by a red bead with a white center.

The list of deaths as furnished by $\mathrm{Dr}$ Waterman's data ends with a bit of blue yarn tied on the thong between the fourth and fifth knots following the $192 \mathrm{~d}$ red Sunday marker, representing the death of certain of Sally's "relatives on Dry creek;" but a pink marker set in the space designating the following Thursday remains without explanation (pl. vI, $b$ ).

The red Sunday markers end with the 225th; from this point onward the Sunday

\section{A N D MONOGRAPHS}




\begin{tabular}{|c|l|}
\hline 52 & \multicolumn{1}{|c|}{ S T R I N G R E C O R D S } \\
\hline $\begin{array}{l}\text { space between the groups of knots, repre- } \\
\text { senting the seven nights of the wee, } \\
\text { remains bare (pl. vI, a). These groups con- } \\
\text { tinue for sixty weeks more, after which } \\
\text { but one day is recorded, which was the } \\
\text { last of June, 1919, according to Dr Water- } \\
\text { man's data. Sally forgot to make a knot } \\
\text { for July 1st, and never resumed the record. } \\
\text { Counting back the weeks from this date, } \\
\text { we find that the death of "Old Jackson" } \\
\text { must have taken place about the beginning } \\
\text { of 1914. } \\
\text { The second and third records, which we } \\
\text { will call Specimens 5 and 6, respectively, } \\
\text { were made by an old Yakima woman } \\
\text { named Mrs Luskin, living at Parker on } \\
\text { Yakima river, but were procured by Dr } \\
\text { Waterman from Emily Paul, also a Yakima, } \\
\text { who could not explain them in detail, but said } \\
\text { that each knot represented a day and each } \\
\text { group of seven knots a week; while the cloth } \\
\text { markers she thought represented "deaths." } \\
\text { An examination of the second example } \\
\text { (Specimen 5), which seems, like the first, } \\
\text { to have been a combined record, not only of } \\
\text { the passing days and weeks, but of certain }\end{array}$ \\
\hline I N D I A N N O T E S \\
\hline
\end{tabular}


important events, shows it to be $32 \mathrm{ft} .7 \mathrm{in}$. long, the first $19 \mathrm{ft} .2$ in. being deerskin, the remainder dogbane fiber. After the first knot, which stands alone, there are 156 groups of 7 knots each, then a single terminal knot, making 1,093 knots in all. There are also 38 markers made of rags, beads. of glass and dentalium, deerskin, yarn, fiber, and red thread, and one human hair caught in a knot. An examination of these shows that in the first part of the record the markers occur on an average of every twenty-nine days, and possibly therefore signify moons, as in the case mentioned by Mr Leechman, but this system seems to have been purposely suspended after about the 15th moon, or some markers may have been lost from the record. Other markers scattered among the "lunar" ones, to the number of 20, may represent deaths, or perhaps other important events. Since the record is not a simple one, like No. 6, and since we have no explanation for it, as we have for No. 4, the following table is presented to show the exact arrangement of the markers as they appear:

\section{A N D MONOGRAPHS}




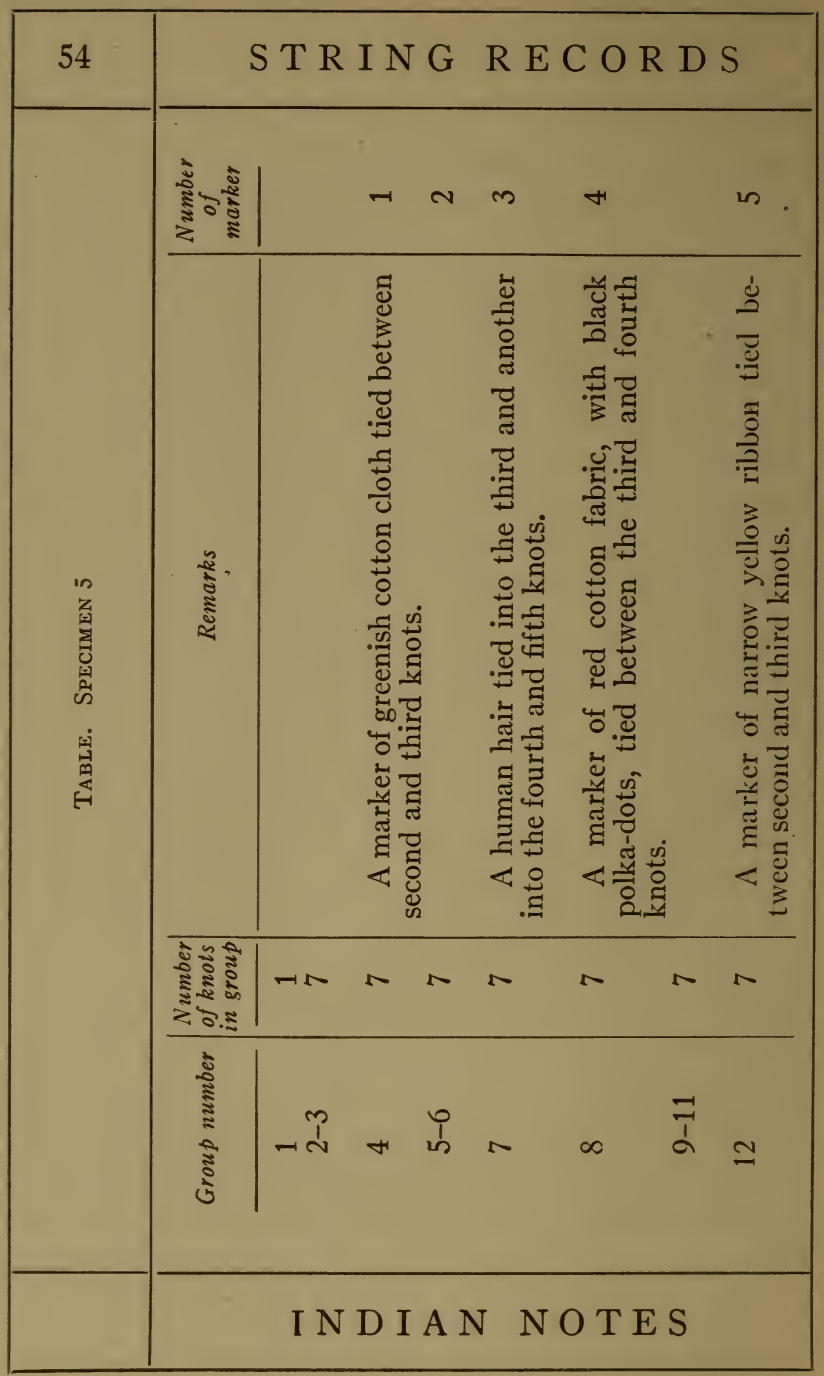




\begin{tabular}{|c|c|c|c|c|c|}
\hline \multicolumn{5}{|c|}{ Y A K I M A } & 55 \\
\hline 0 & N & $\infty$ & $a \cong$ & $\Rightarrow$ & \\
\hline 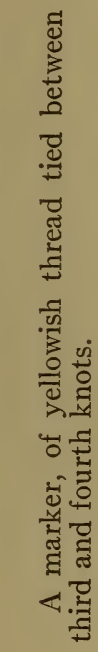 & 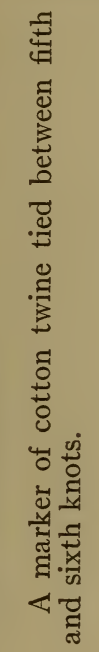 & 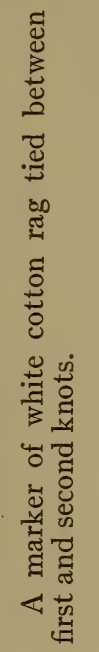 & 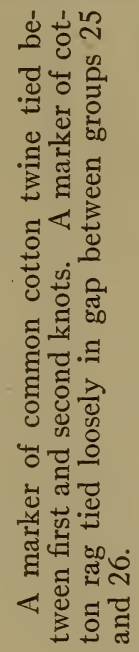 & 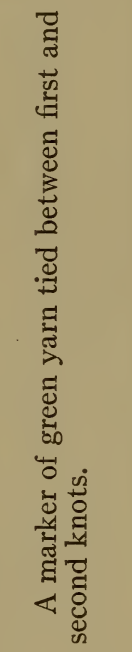 & \\
\hline An & na & -1 & $n$ & n & \\
\hline$\approx \pm$. & 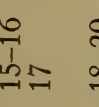 & ț & ㅂํำ & $\begin{array}{l}\text { స్ } \\
\text { స్సి } \\
\tilde{్} \\
\end{array}$ & \\
\hline & N D 1 & $\mathrm{MON}$ & $\mathrm{R} A \mathrm{P}$ & & \\
\hline
\end{tabular}




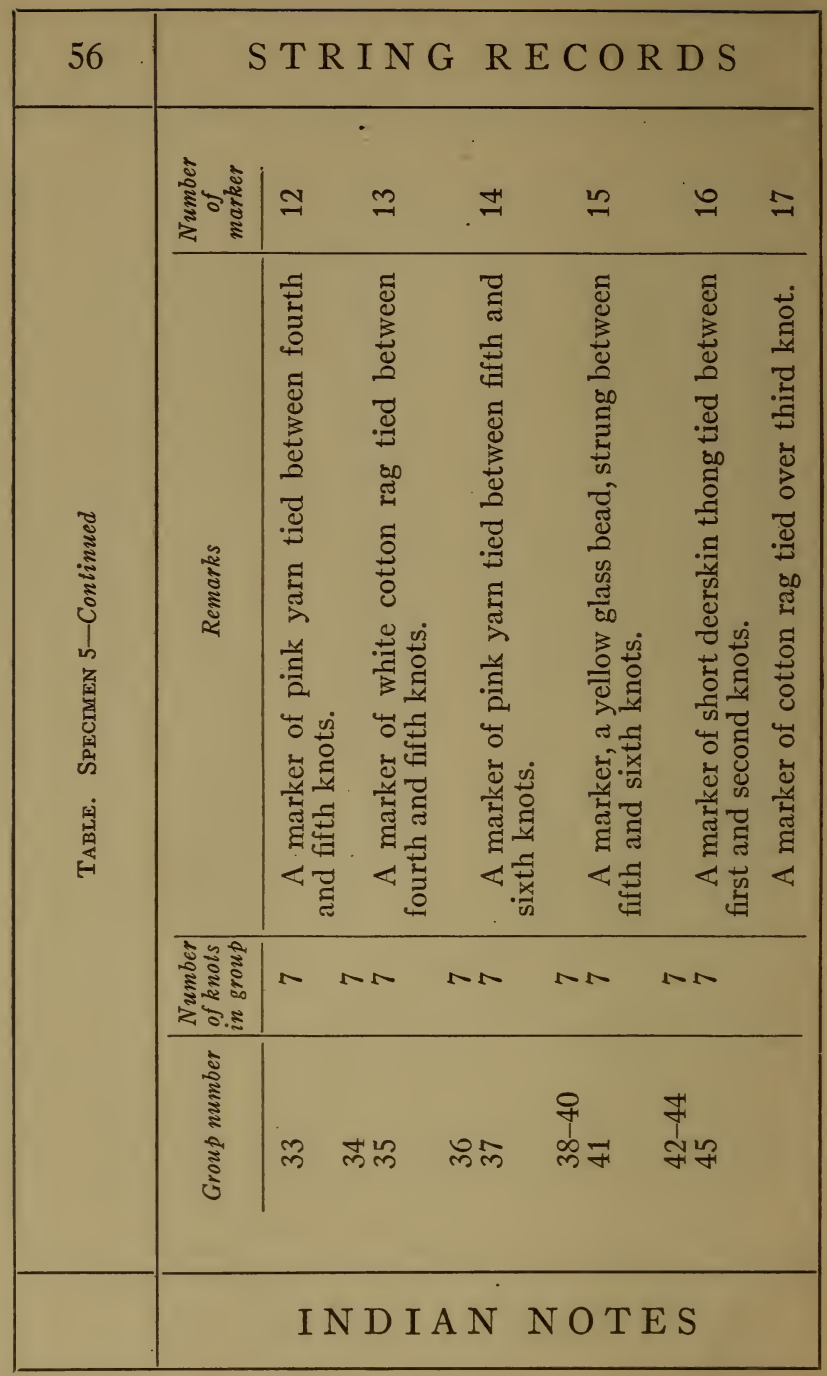




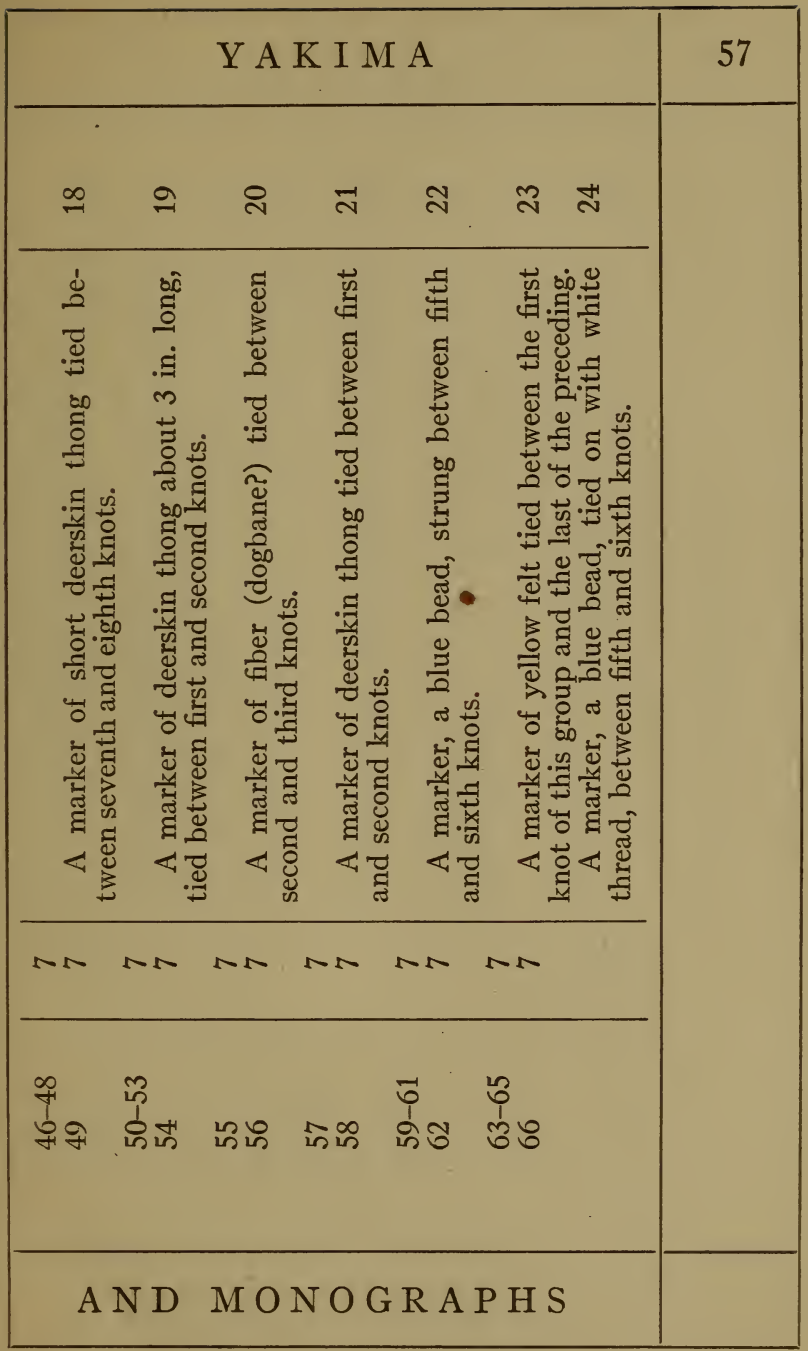




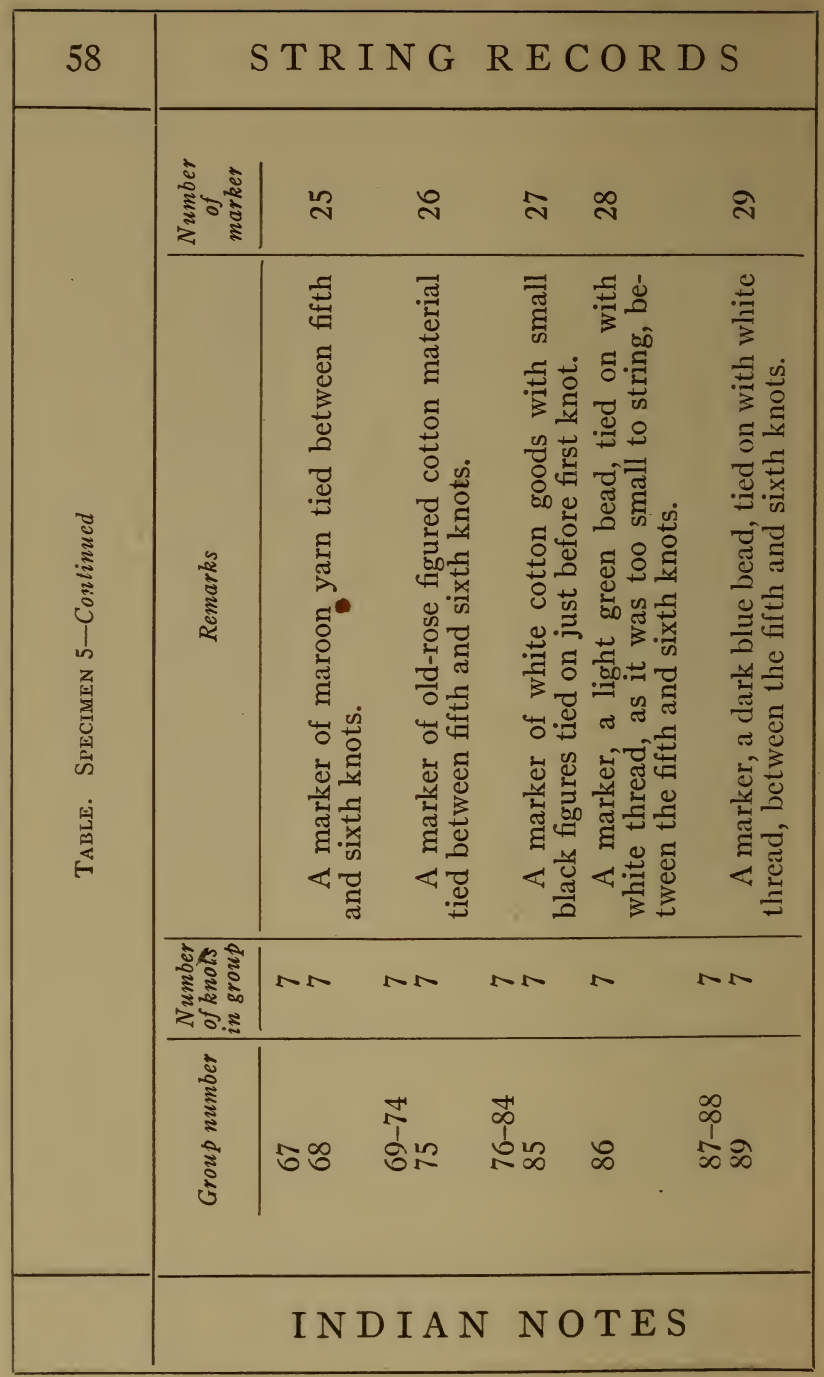




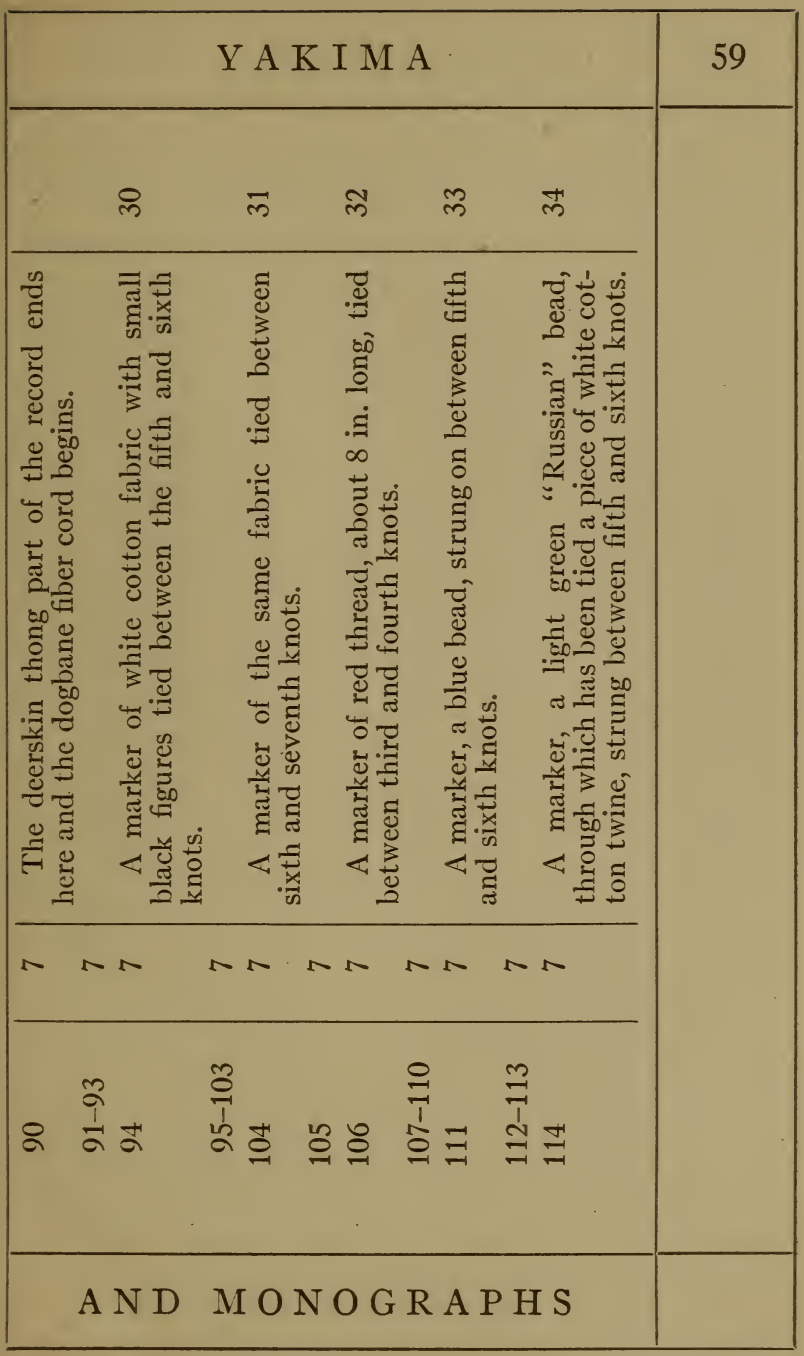




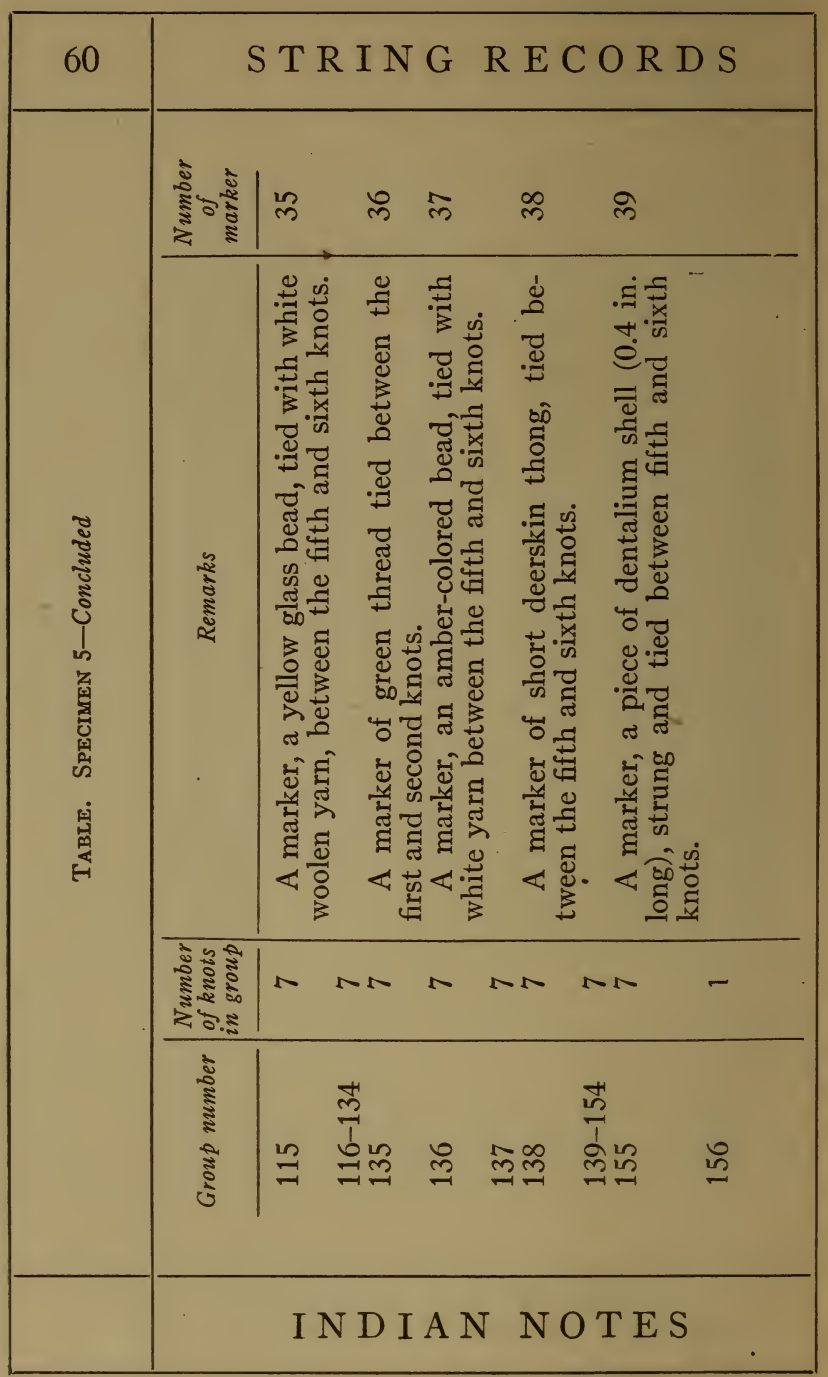


The third record (Specimen 6 ) is the shortest of all, measuring only $13 \mathrm{ft} .4 \mathrm{in}$. in length, and is made entirely of fiber. It begins in an unusual manner with four small knots, followed by a black bead, then another knot, then a bead, then a knot, then a space 1.8 in. long, in which are strung 7 black beads followed by a knot; then comes 8 in. of bare fiber cord, then a group of 2 knots, after which the groups of 7 knots each run to the number of 73 , with one group of ten knots. After the 60th group the Sundays are marked by blue "Russian" beads, instead of by the simple gaps between the groups, and the moons are indicated throughout by tufts of yarn (pl. vi,e) or rag placed at intervals of from twentyfour to thirty-two knots. Only six days of the last week are recorded, after which the string is occupied by 24 green and blue glass beads of the "Russian" variety, evidently intended for marking succeeding Sundays. Nothing but the succession of days, weeks, and moons, seems to have been preserved in this record. It seems purely chronological, a "calendar string," unless the "moon"

\section{A ND MONOGRAPHS}




\begin{tabular}{|l|l|}
\hline S T R I N G R E C O R D S \\
\hline $\begin{array}{l}\text { markers, as suggested below, may have } \\
\text { another meaning. } \\
\text { The possibility that the use of these } \\
\text { records, called iti ta'mat by the Yakima, } \\
\text { may not be very old among these Indians } \\
\text { is suggested by the fact that all or most of } \\
\text { them are based on our modern week of } \\
\text { seven days, which is certainly not a native } \\
\text { concept-yet the "moons" recorded by } \\
\text { the markers in some of the strings are not } \\
\text { calendar months by any means, but per- } \\
\text { haps an attempt to indicate lunar months, } \\
\text { a native concept. Possibly the original } \\
\text { string records of these tribes were concerned } \\
\text { only with days and moons. It is interesting } \\
\text { to note that such records seem to have been } \\
\text { kept only by the women, which fact leads } \\
\text { to a speculation as to whether the so-called } \\
\text { "lunar month" markers may not in real- } \\
\text { ity represent menstrual periods, which would } \\
\text { account for their irregularity of placement } \\
\text { (ranging in one record from 24 to 32 days } \\
\text { apart) and their entire absence from some } \\
\text { parts of the records. } \\
\text { Chronological if not biographical string } \\
\text { records are not unknown in other parts of }\end{array}$ \\
\hline \multicolumn{1}{|c|}{ I N D I A N N O T E S } \\
\hline ald
\end{tabular}


North America; Lumholtz, ${ }^{1}$ for example, reporting them from the Huichol Indians of northe:n Mexico; while Mr F. W. Hodge informs the writer that he has seen Zuni laborers keep account of each day's work by tying a knot in a string carefully kept for that purpose.
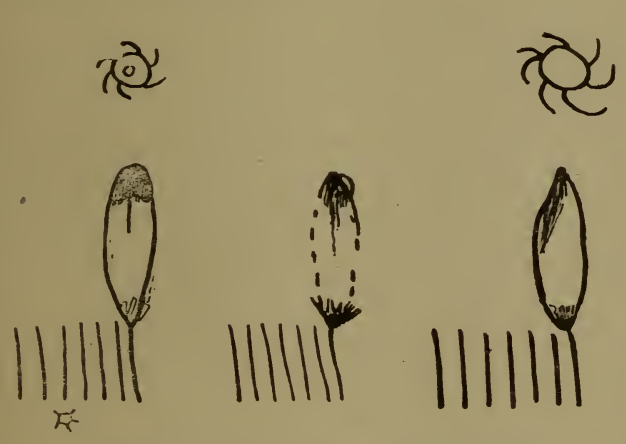

Fig. 1.-Weekly Calendar of the Kiowa.

The writer has noticed the existence among Indians in other parts of the United States of other native inventions intended particularly to help the uneducated members of the tribes to "keep track of Sunday."

\section{A N D MONOGRAPHS}




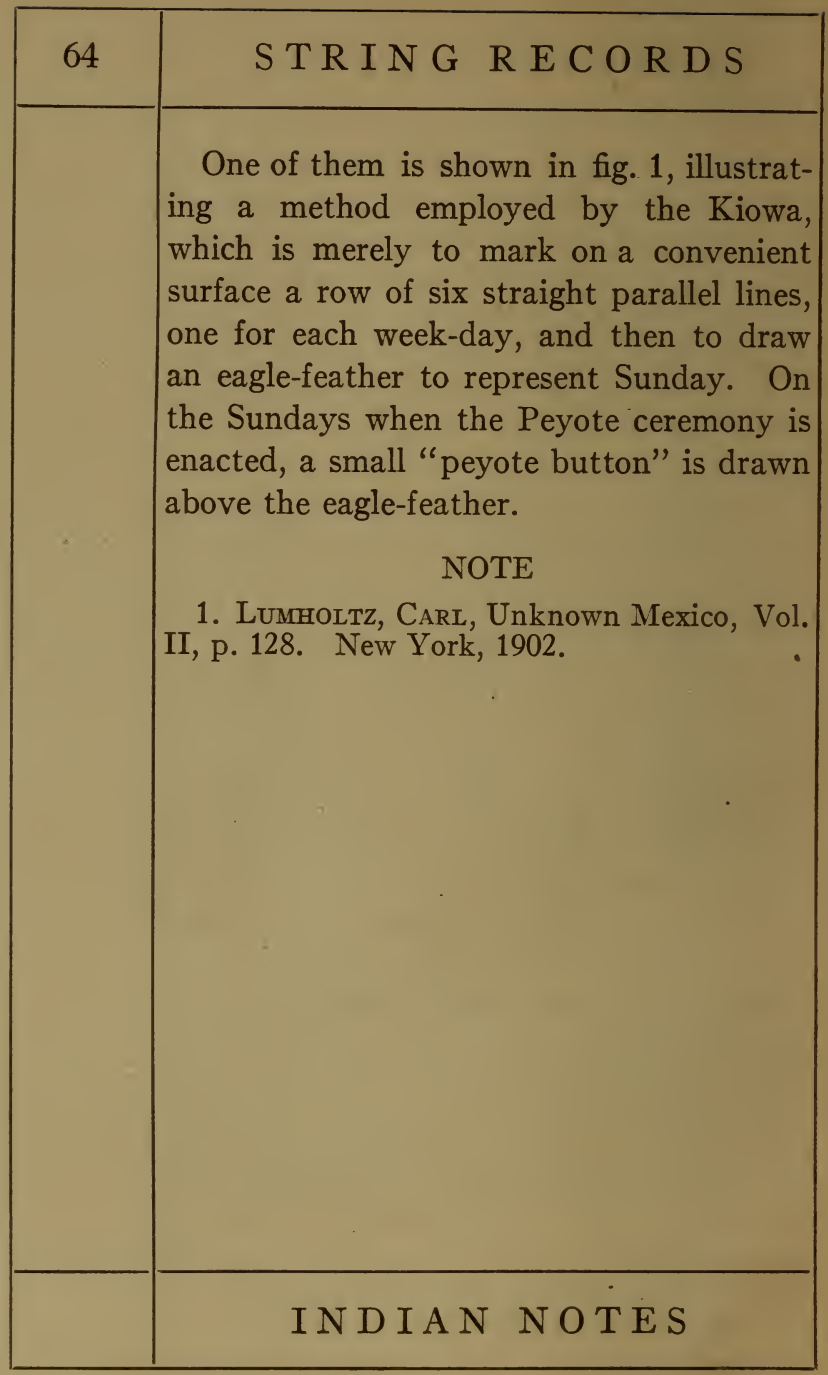




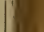


SMTHSONIAN INSTITUTION LIBRARIES

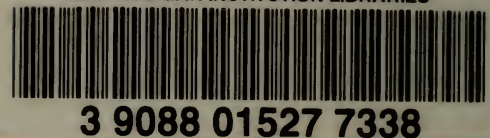

